\title{
EUCHARISTIC REFERENCES IN THE REPRESENTATIONS OF SAINTS: A CASE STUDY OF LATE GOTHIC WALL PAINTINGS IN TRANSYLVANIA
}

\begin{abstract}
Eucharistic references in the representations of saints constitute a relatively unexplored segment within the iconography of the Holy Sacrament. This article analyses a number of hagiographical compositions from the Late Gothic wall paintings of Transylvania, which seem to carry eucharistic connotations, either through explicit references to the Sacrament (in the form of a monstrance, a chalice or host-shaped bread) or through subtler allusions to the sacrificial Body of Christ present in the Eucharist. The fact that most of these images are located in the sanctuaries of churches and are typically associated with other, more straightforward eucharistic imagery suggests conscious choices on the part of the inventors of the iconographic programs in adapting the subject matter of the wall paintings to the function of the given liturgical space.

Keywords: Transylvania, wall painting, iconography, Late Gothic, 15th century, 16th century, Eucharist, Saint Paul the Hermit, Martyrdom of the Ten Thousand, Martyrdom of Saint Ursula, Saint Valentine, Saint Fabian, Saint Sebastian, Veronica's veil, Saint Barbara, Mary Magdalene
\end{abstract}

The interconnection between monumental art decorating different parts of a church and the liturgical and devotional practices taking place there is an intriguing question within the study of medieval church interiors. ${ }^{1}$ This relationship is most evident in the case of representations connected to the Eucharist, which are concentrated in the chancel area, corresponding to the eucharistic liturgy performed at the high altar. ${ }^{2}$ With the intensification of the eucharistic cult in the later middle ages, new iconographic themes have emerged, besides already existing ones, to visualise this central mystery of Christian faith and serve new devotional needs. ${ }^{3}$ In this article I focus on a single segment of the rich and varied complex of representations related to the Eucharist, studying eucharistic references in the depictions of saints in the Late Gothic wall painting decoration of sanctuaries in Transylvania. The article seeks to answer the following questions: how and to what extent can hagiographical representations primarily associated with the cult of saints convey a message related to the eucharistic cult, and what role do these representations play in the iconographic programs of the sanctuaries.

\section{OVERVIEW OF PREVIOUS RESEARCH}

While much attention has been devoted to the relationship between art and the Eucharist in general, hagiographical representations have been less studied

* Anna Kónya, PhD candidate, Department of Medieval Studies, Central European University, Budapest, Hungary; e-mail: konya_anna@phd.ceu.edu in this respect. The most comprehensive overview on the subject is a chapter in Maurice Vloberg's monograph on eucharistic themes from 1946, listing and presenting sixteen saints from the pre-Tridentine period associated with the Eucharist in their iconography, mostly based on their special devotion to the Holy Sacrament. ${ }^{4}$ In an introductory study to 
the catalogue of the exhibition accompanying the 1960 Eucharistic congress in Munich, Franz Dambeck examines the spread and typology of eucharistic attributes. He argues that although the equipment of a saint with a chalice and a host, a monstrance or a ciborium is never meant as a generic attribute suggesting priestly profession, but is always based on a specific episode of the vita, the actual reason behind this iconographical choice is the promotion of the eucharistic cult through the example of the saints. ${ }^{5}$ Analysing the decoration programmes of sacrament houses, Achim Timmermann introduces the concept of typology to account for the presence of saints on tabernacles, arguing that symmetrically to Old Testament prefigurations of Christ, the saints, whose life was modelled on that of Christ, can be conceived as His postfigurations. In his view, cases when the actions, miracles or intercessory powers of a saint are associated with the Eucharist can also be interpreted as typological analogies. ${ }^{6}$ In a study similarly concerned with analogies between hagiographical narratives and the life of Christ, but focused on the episodes of torture and death, Daria Dittmeyer maintains that in some cases eucharistic symbolism was used when drawing a parallel between the martyrdom of a saint and Christ's death on the cross, both in hagiographical texts and in images. For the latter, the author gives examples of fifteenth-century representations of the martyrdom of Saint John the Baptist and that of Achatius and the ten thousand martyrs. ${ }^{7}$

As these studies of eucharistic motifs in the iconography of the saints suggest, while some saints - like Saint Barbara or Saint Claire of Assisi - recur in most surveys, there is no easily definable category of "eucharistic saints." Neither was there a single pattern for how a saint came to be associated with the Holy Sacrament, as the reasons could range from the saint's own fervent eucharistic devotion through miraculous actions or posthumous intercessory powers related to the Sacrament to details of their suffering and death evoking Christ's body on the cross, identical to the consecrated bread and wine of the Eucharist.

\section{CASE STUDIES}

Alsóbajom (Boian, Bonnesdorf), parish church

On the northern sanctuary wall of the parish church in Alsóbajom two fragmentary scenes datable to around 1500 survive. In the lower tier, a hexagonal architectural structure fills about three quarters of the composition, under which the figures of Saint Sophia and her three daughters appear (Fig. 1). To the right of the building, against the background of a green hill, a monastic saint is standing (Fig. 2). His face is destroyed, the lower part of his fragmentary figure is not revealed. A halo encircles his tonsured head, he is grey-haired and bearded. He is wearing a dark brown monastic gown, and a white habit underneath fastened with a black belt. He is holding an open book in his right hand and a staff in his left, while pointing to the book with his index finger. Although the ending of his staff is partly destroyed, the remaining outlines suggest that it was T-shaped. From the upper right corner of the scene, a black bird comes flying in the sky, bringing nourishment to the saint in its beak.

The saint has been identified differently as either Saint Anthony the Great ${ }^{8}$ or as Saint Paul the Hermit. ${ }^{9}$ Although, according to his legend, Saint Paul the Hermit wore a garment of palm-leaves stitched together, ${ }^{10}$ and the monastic attire the saint is wearing, and his attributes are typical for Saint Anthony's iconogra- phy, ${ }^{11}$ Saint Paul was sometimes represented similarly to Saint Anthony, in a monastic habit, holding a T-staff or a book. ${ }^{12}$ The motif of the raven bringing bread is taken from an episode of the life of Saint Paul the Hermit. With the occasion of Saint Anthony's visit, as a bird brings them a loaf of bread for meal, Paul explains to his amazed guest that God has been feeding him in this way for sixty years. ${ }^{13}$ The raven with a bread in its beak appears either on narrative scenes depicting the meeting of the two saints, an episode often included in Saint Anthony cycles, or as an attribute of Saint Paul the Hermit, but is not among the known attributes of Saint Anthony.

In this way, an identification of the saint as Saint Paul the Hermit seems more convincing. As opposed to Saint Anthony the Great, who appears in a number of Transylvanian altarpieces and wall paintings, ${ }^{14}$ no other alone standing representation of Saint Paul the Hermit is known from the region..$^{15}$ At the same time, Saint Paul the Hermit had a significant cult in late medieval Hungary, centred around his relics acquired in 1381 from Venice and kept in the monastery of Budaszentlofrinc - the center of the Pauline order -, which had become a pilgrimage place of national importance. ${ }^{16}$ The order named after the saint was also one of the most popular monastic communities, with 


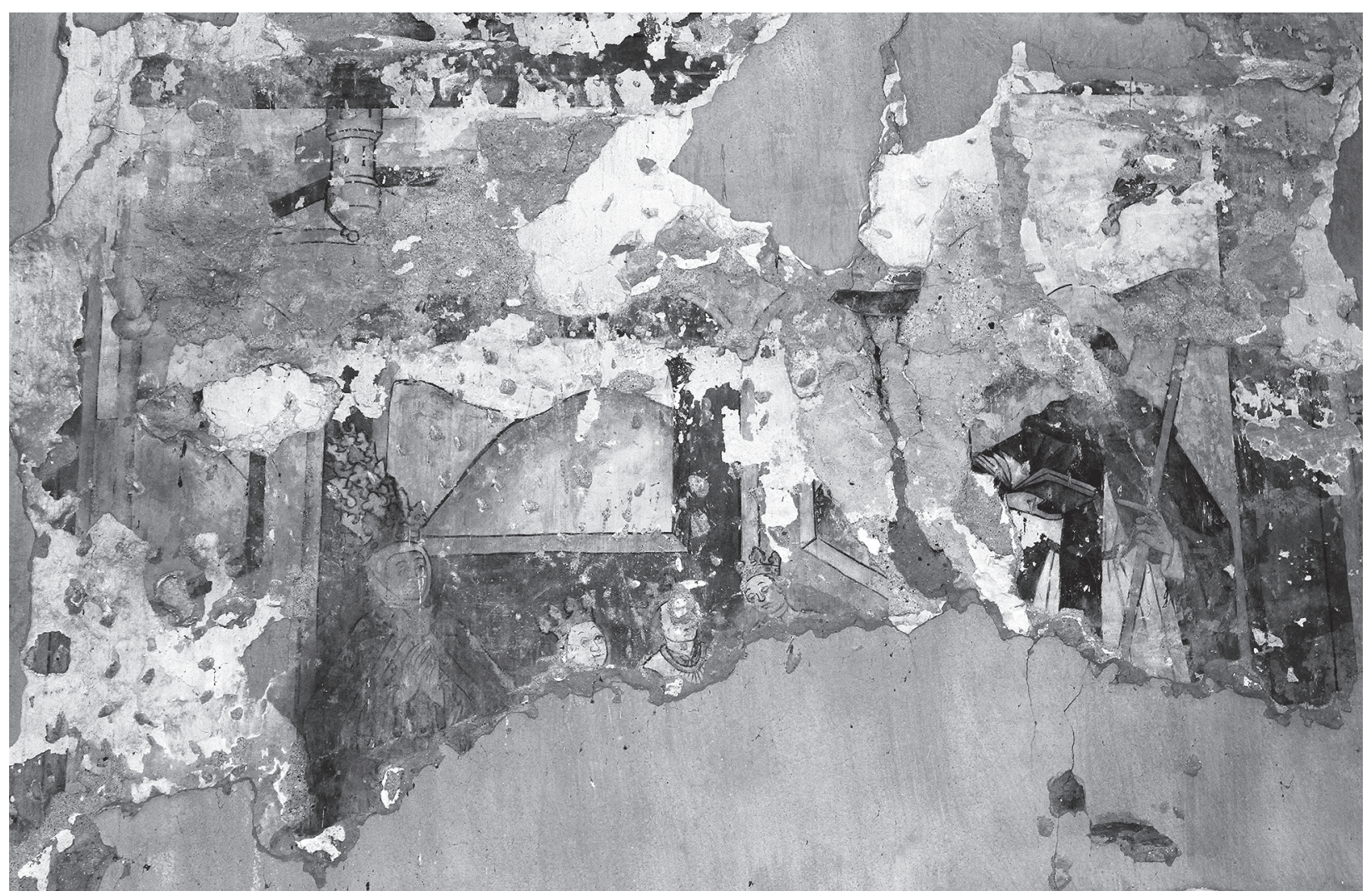

Fig. 1. Saint Sophia with her three daughters, and Saint Paul the Hermit fed by a raven; Alsóbajom, parish church (photo by the author)

around 75 monasteries in the Hungarian Kingdom by the end of the fifteenth century. One of these, the monastery of Pókafalva (Păuca, Törnen) founded in 1416 by Ladislaus, Provost of Szeben was situated not far from Alsóbajom; however, it was destroyed during Ottoman attacks in the middle of the fifteenth century. ${ }^{17}$

The detail of the raven bringing bread to feed the saint deserves attention for several reasons (Fig. 3). According to his legend, Saint Paul received half a loaf of bread each day during the sixty years of his retreat in the desert, the portion being doubled on the occasion of Saint Anthony's visit. ${ }^{18}$ In representations of the meeting of the two saints the bird carries either an undivided round bread or a loaf formed of two halves, following the text of the Golden Legend. ${ }^{19}$ This motif is in most cases depicted similarly - if somewhat inconsequently - in the alone standing representations of Saint Paul the Hermit. On a fifteenth-century keystone possibly originating from the Pauline monastery of Budaszentlorinc, consistently with the text of the legend, the saint receives a half bread. ${ }^{20}$ In the representation in Alsóbajom, however, the disk-shaped object in the bird's beak resembles not so much a loaf of bread, as a Host wafer.
The model for this episode of Saint Paul's legend was the Old Testament story of prophet Elijah, which Jerome used as a source of inspiration for his Vita Pauli. ${ }^{21}$ The passage of the prophet being fed with bread by ravens in the desert (1 Kings 17:6) has generally been interpreted as a prefiguration of the Eucharist. ${ }^{22}$

The meal consumed by Saint Paul and Anthony also resembles a communion in some respects, in fact, the last communion of Saint Paul before his death. Before eating it, the two saints break the bread sent from heaven, then drink from a spring, offering to God the sacrifice of praise (Lat.: sacrificium laudis), a phrase familiar from the eucharistic prayer of the Canon of the Mass. Shortly thereafter, Saint Paul attains in his death the union with Christ that he has always longed for. ${ }^{23}$

Accordingly, depending on its iconography and the context of its placement, the representation of the meeting of Saint Paul and Saint Anthony can be seen as a reference to the Eucharist. On several eighteenth-century Irish and Anglo-Saxon high crosses the eucharistic meaning of the episode was emphasised by an inscription referring to the liturgical moment of the fractio panis, the inclusion of a chalice besides the heavenly bread into the composition, or the juxtaposi- 


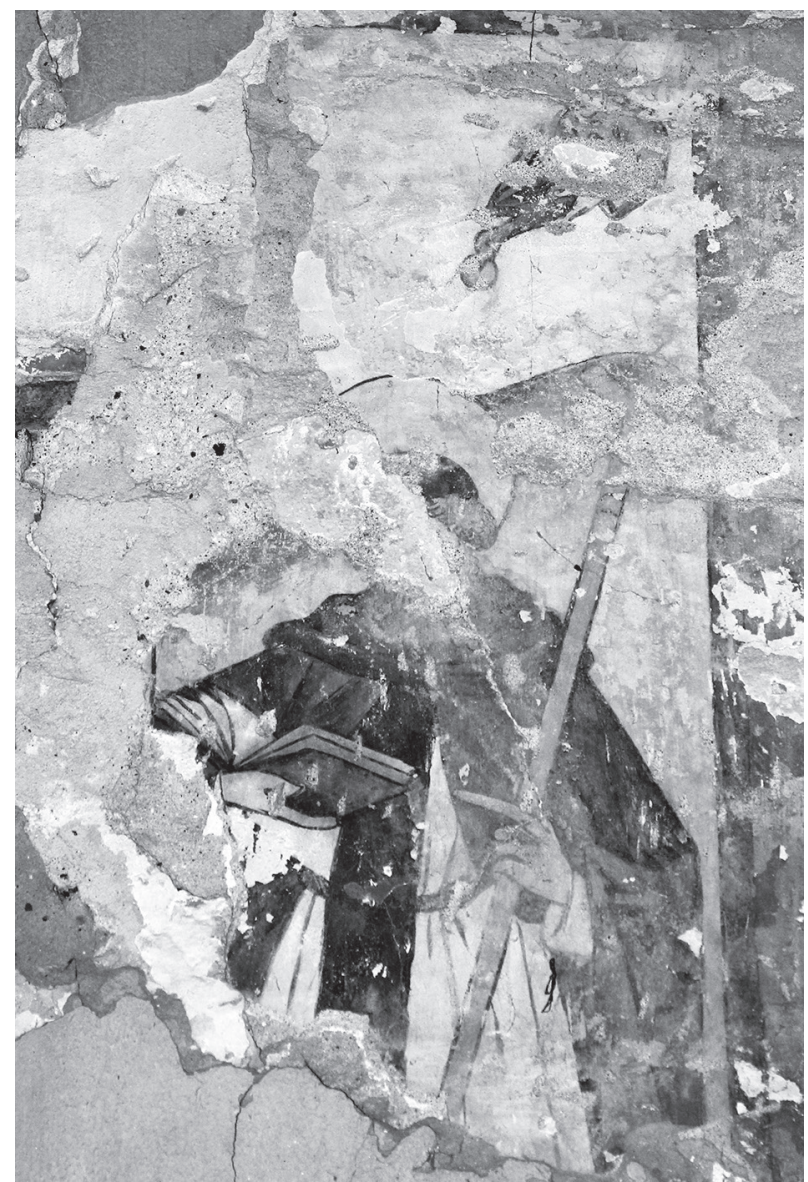

Fig. 2. Saint Paul the Hermit fed by a raven; Alsóbajom, parish church (photo by the author)

tion of the scene with other representations referring to the Eucharist. ${ }^{24} \mathrm{~A}$ panel of a stained glass window representing scenes from the life of Saint Anthony in the south ambulatory of Chartres Cathedral, made after 1220, has similarly been interpreted in eucharistic terms (Fig. 4). The composition merges two consecutive moments of the narrative: the - this time dove-like - bird heading almost vertically downwards with a white wafer-shaped bread marked with a cross, and the two saints each grabbing a part of the bread to share it, their intersecting arms also forming a cross. ${ }^{25}$

Although the exact reasons behind the inclusion of this rare representation of Saint Paul the Hermit in the iconographic program in Alsóbajom can no longer be reconstructed, one of them was probably the eucharistic connotation of the image, suiting the liturgical context of the sanctuary.

It is interesting to note the unusual iconographic solution wherein, behind the raven acting as an agent of divine providence, the half figure of God the Father sending off the bird appears (the head of the fragmentary figure has been destroyed). A similar emphasis on

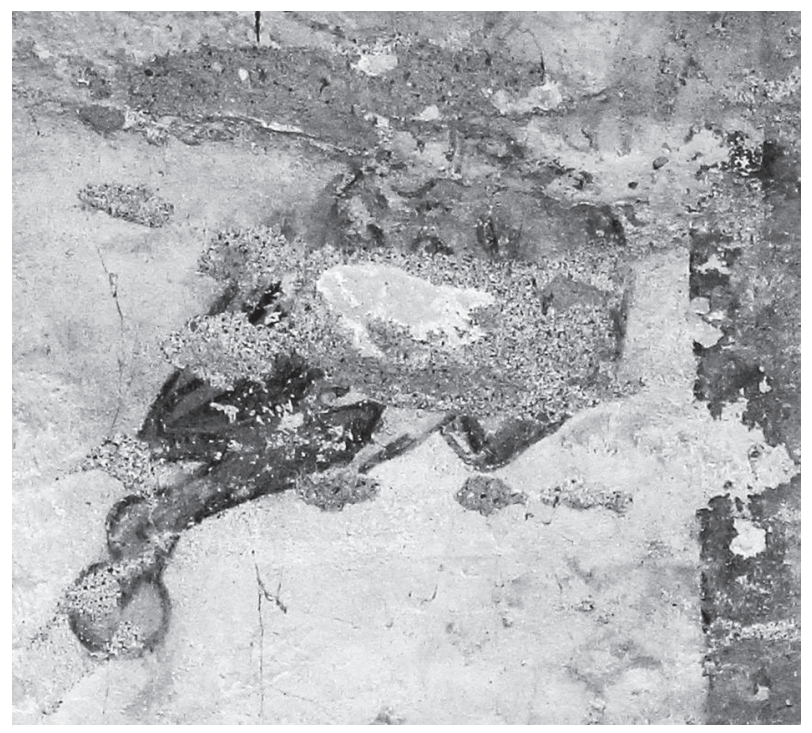

Fig. 3. Saint Paul the Hermit fed by a raven (detail); Alsóbajom, parish church (photo by the author)

divine providence and the heavenly origin of the bread sent to the two saints can be observed in an altarpiece panel housed in the Kunstmuseum of Basel from 1445, where the figure of God the Father surrounded by a host of angels appears in a cloud in the upper part of the scene depicting the meeting of Saint Paul and Anthony (Fig. 5). ${ }^{26}$

The subject of the representation in the upper tier is the Martyrdom of the Ten Thousand (Fig. 6). The martyrs, who were thrown from the Mount Ararat into a thicket of thorns because of their conversion to Christianity, appear in varied convoluted postures, their limbs and torsos being pierced through by the sharp green branches. Their figures are naked but for their loincloths. Their leader, Achatius, appears as a beardless young man around the middle of the composition, being differentiated from his soldiers by a red princely hat. The haloed bishop saint in the foreground, reading from an open book held in his hand, is probably Hermolaus, who, according to one version of the legend, baptised the soldiers of Achatius, and consequently suffered martyrdom with them. ${ }^{27}$

In the legend version published in the Acta Sanctorum, there are numerous allusions to the biblical Passion story. After the recently baptised soldiers refuse to offer sacrifice to the pagan gods, among other tortures they are scourged and mocked, crowned with crowns of thorns, their sides are pierced through with sharp reeds, they are greeted as "kings of the Jews," and are finally crucified at the order of king Maximianus. ${ }^{28}$ Explicit references to Christ's sacrifice are also made in the legend, by pointing to the similarities in 


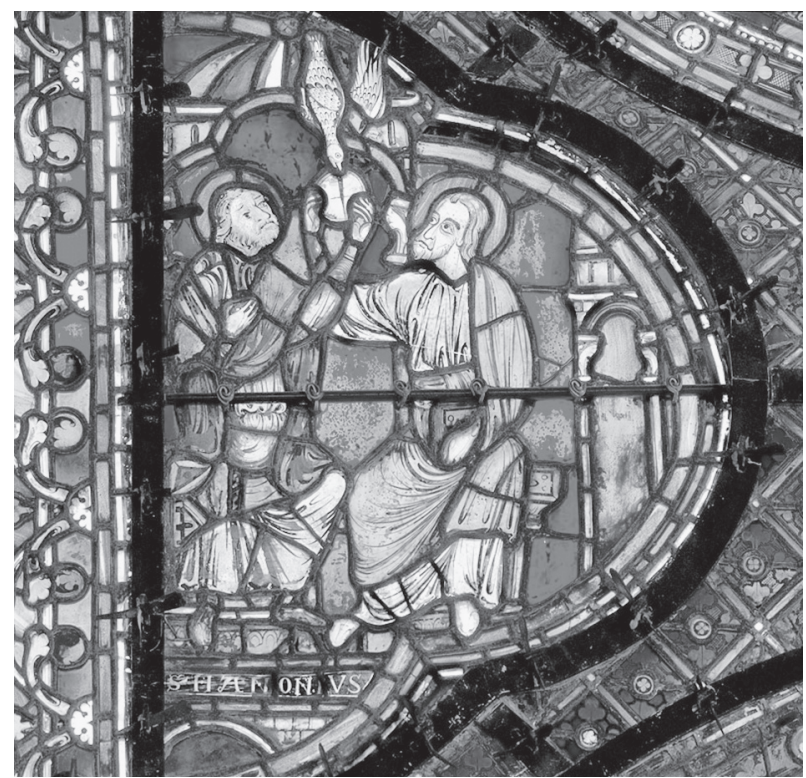

Fig. 4. The meeting of Saint Paul and Saint Anthony; Chartres Cathedral

( Stuart Whatling, http://www.medievalart.org.uk)

the types of torture, ${ }^{29}$ but also in a conception of martyrdom as sharing in Christ's sufferings, for which the martyrs pray to be worthy of. ${ }^{30}$

This endeavour to present the martyrs' suffering as analogous to that of Christ is also traceable in visual representations. ${ }^{31}$ Even though the episode of the legend usually captured is not the crucifixion of the martyrs, but their impaling on thorns, ${ }^{32}$ references to Christ's sufferings are common from the fourteenth century onwards. In several representations, Achatius appears in a posture reminiscent of the crucified Christ in the centre of the composition, amongst his soldiers impaled on the thorn bushes. ${ }^{33}$ An example of this type is a wall painting decorating the northern nave wall of the parish church in Medgyes (Medias, Mediasch) from around 1420, although here the central figure represented with wide-spread arms, evoking the crucified Christ, is most probably based on his mitre, bishop Hermolaus, and not Achatius (Fig. 7). ${ }^{34}$ In a particularly bloody rendering of the theme on a diptych in the Wallraf-Richartz-Museum in Cologne from around 1325-30, the wounds caused by the sharp thorns on the martyrs' bodies exactly correspond in position and number to the five wounds of Christ, further emphasising the analogy. ${ }^{35}$

In some cases the usual martyrdom in the thorn bushes is complemented with the episode of the crucifixion of the ten thousand martyrs, most famously in Dürer's painting housed in the Kunsthistorisches Museum in Vienna (1508), where the crucifixion scene

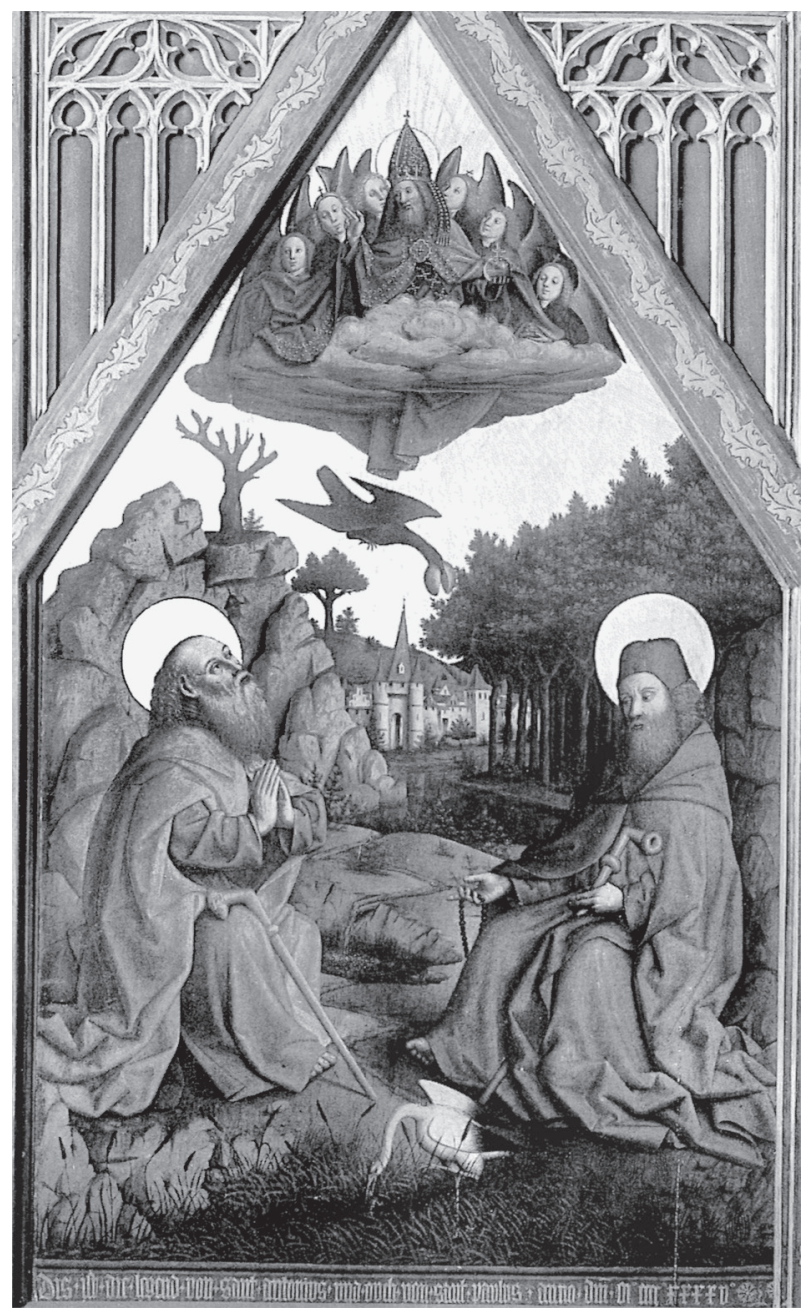

Fig. 5. The meeting of Saint Paul and Saint Anthony, 1445; Basel, Kunstmuseum (FleischHAUER, op. cit., 49)

in the bottom left corner contains various references to the Passion of Christ, ${ }^{36}$ which have led Panofsky to describe it as a "reenactment of the Calvary" and a "symbol of the Imitatio Christi" (Fig. 8) ${ }^{37}$ In a panel of the All Saints' altar in the Abbey Church of ReichenauMittelzell, several consecutive episodes of the legend modelled on Christ's sufferings are represented in the foreground of the composition, such as the flagellation, the coronation with crown of thorns and the crucifixion, while the conventional impaling by thorns is relegated to the background, in a barely recognisable way.

In the fifteenth century a specific compositional type has emerged, combining the martyrdom scene with the crucifixion of Christ into one composition. ${ }^{38}$ This type was also widespread in the territory of Medieval Hungary, appearing in several altarpieces from Upper Hungary, ${ }^{39}$ and in the altarpiece of the Transylvanian Nagyekemezô (Târnava, Grossprobtsdorf; c. 1490-1500, Fig. 9). ${ }^{40}$ On these compositions a marked 
visual parallel is suggested between the bodies of the martyrs naked but for their loincloths, bleeding from the thorn-made wounds, and the centrally placed figure of the crucified Christ rising above them, bearing the wounds of the nails and the lance.
Beyond being an illustrative example of the idea of martyrdom as imitatio Christi, several authors note that the martyrdom of the ten thousand could be a specifically eucharistic theme, which in several cases was part of the iconographic programs of the sanctuaries. ${ }^{41}$

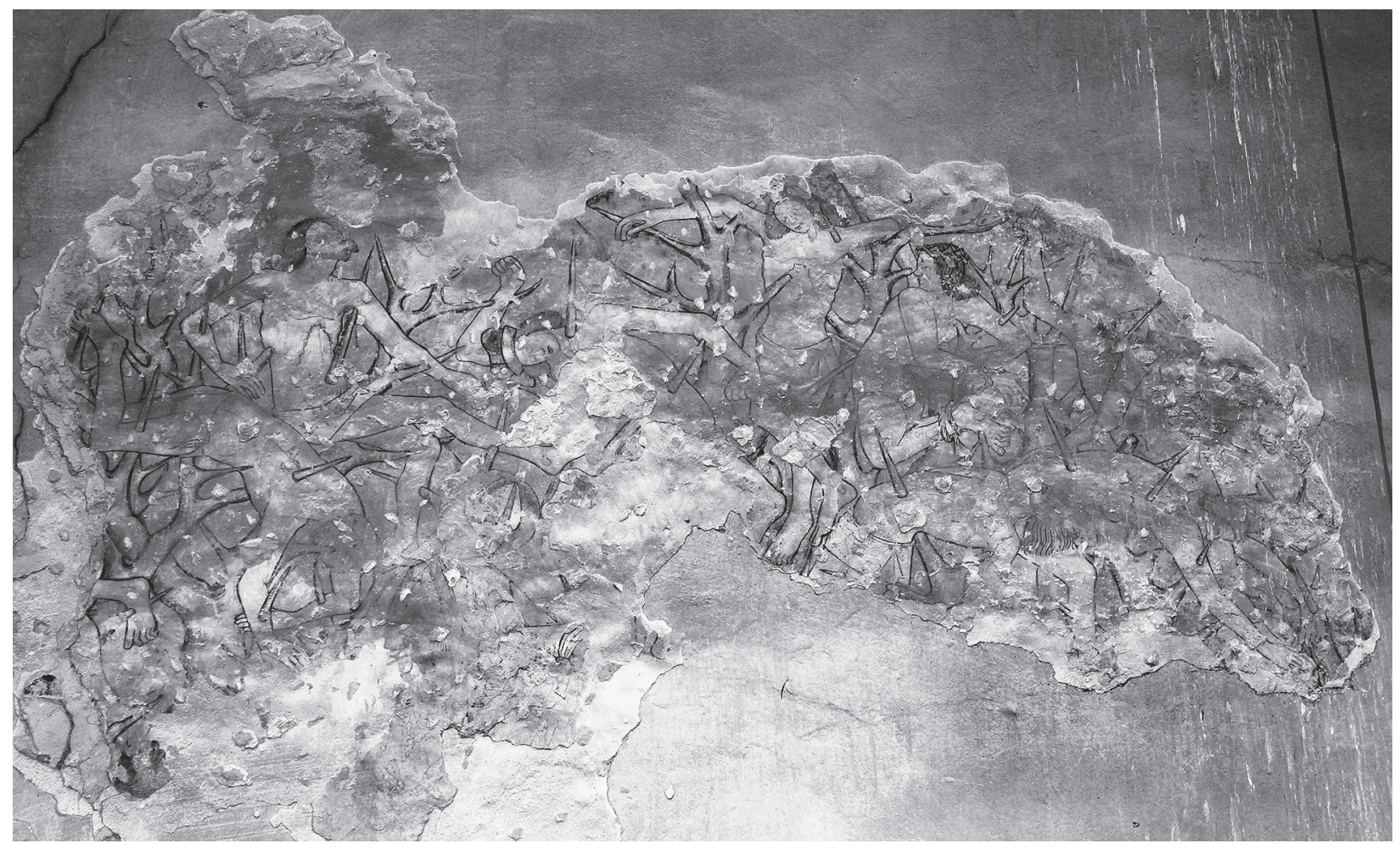

Fig. 6. Martyrdom of the Ten Thousand; Alsóbajom, parish church (photo by the author)

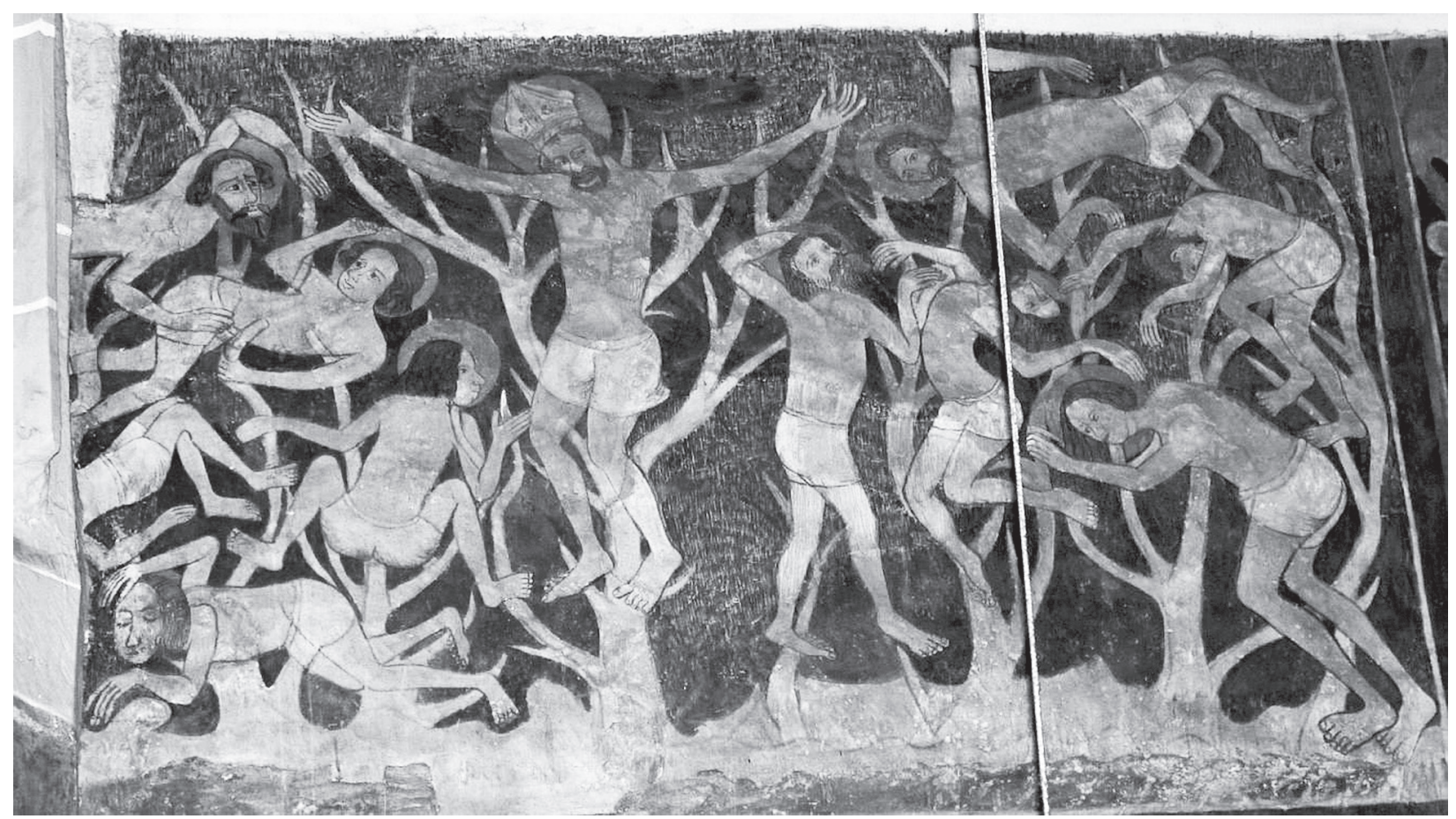

Fig. 7. Martyrdom of the Ten Thousand; Medgyes, parish church (photo by the author) 


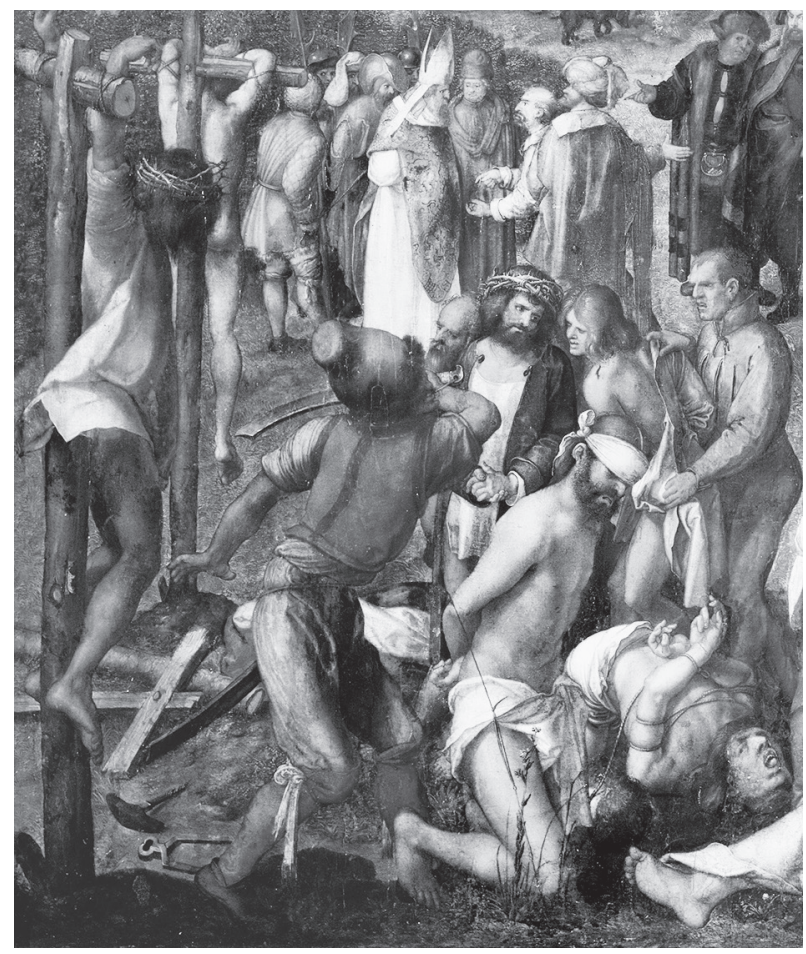

Fig. 8. Albrecht Dürer: Martyrdom of the Ten Thousand (detail); Vienna, Kunsthistorisches Museum (C) KHM-Museumsverband)

In the church of the Assumption of the Virgin in Krzyzowice (Silesia, Poland), the theme appears as part of a series of Christological compositions surrounding the sacrament niche on the south-eastern sanctuary wall (Fig. 10). ${ }^{42}$ Above the tabernacle flanked by two angels holding candles, the Holy Face appears. To the right, a so-called eucharistic Man of Sorrows with the Arma Christi was represented and an angel collecting the blood flowing from Christ's side wound into a chalice. To the left, Christ appears crucified on the Tree of Life, surrounded by ten martyrs (each symbolising a thousand) impaled on thorns, as well as the figures of bishop Hermolaus at the foot of the arbor vitae, and the half figure of God the Father above in the clouds. The martyrdom of the ten thousand is also associated with eucharistic themes in an altar panel from Grodków (also in Silesia), where the combination of the martyrdom with a three-figure Crucifixion scene is complemented with a smaller scale Mass of Saint Gregory in the foreground. ${ }^{43}$

Even though the composition from Alsóbajom has survived fragmentarily, an emphasis on motifs evoking the Passion of Christ can be observed. The beardless young martyr to the right from Achatius, but similar to him in appearance and physiognomy, unlike his

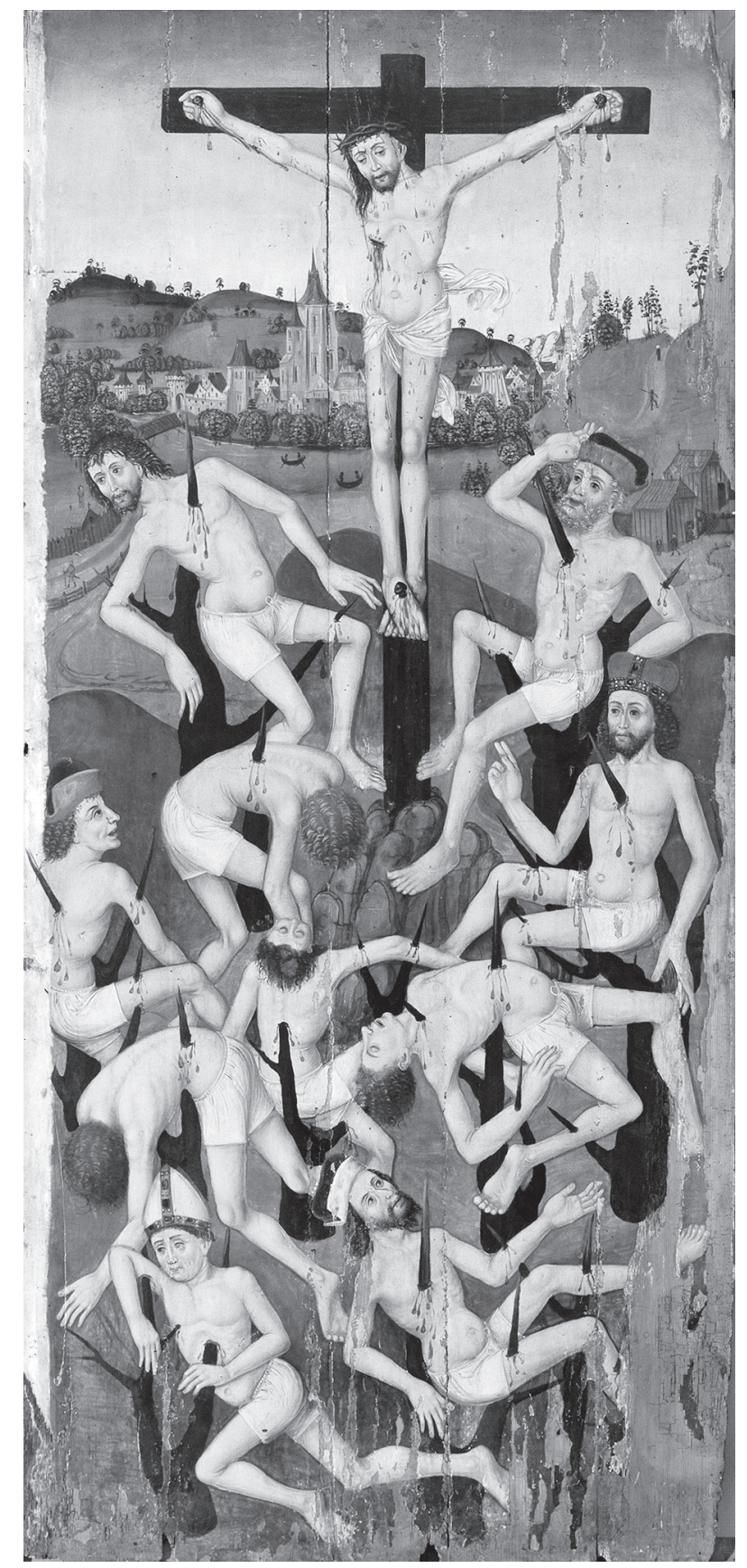

Fig. 9. Martyrdom of the Ten Thousand, stationary wing of the altarpiece from Nagyekemezö; Sibiu, Brukenthal Museum (photo credit: Institute for Material Culture - University of Salzburg)

companions depicted in various convoluted postures, appears in an upright position, with outstretched arms reminiscent of the Crucifixion, a thorn piercing through his side at the place where the lance of Longinus had wounded Christ's chest. The next martyr, whose arms and legs are tied together with a rope in the back, is wearing a crown of thorns (Fig. 11). 
Nagyszeben (Sibiu, Hermannstadt), former church of the Dominican nunnery

A somewhat later representation of the same theme can be found in the former church of the Dominican nunnery in Nagyszeben, as part of a complex iconographic program decorating the southern sanctuary wall (c. 1510-20, Fig. 12). ${ }^{44}$ The martyrdom of the ten thousand is painted here as the first scene from the left in the upper tier. In the upper left part of the composition the executioners are tossing down the martyrs with the help of a long stick from a steep rock of Mount Ararat into a valley inhabited by spikybranched bushes. Two martyrs are captured in different stages of the movement of falling down, while eight of their companions are suffering below in the valley, their torsos impaled on the spikes, blood flowing from their wounds in streams. The postures of the martyrs are more repetitive here than in the composition in Alsóbajom, most figures appearing in a lying position, either facing upwards or the ground, with their arms tied together behind their back, only one of them is kneeling. The top of the cliff overgrown with grass on the right of the scene is the site of another episode. In the foreground, the martyrs are stripped of their clothes. Behind, the figures of seven martyrs crucified on crosses are discernible (Fig. 13).

The scene seems to be thematically linked to two other compositions of the cycle. The third scene of the upper tier is the martyrdom of Saint Ursula and the eleven thousand virgins. Representations of the two legends involving mass martyrdoms are often juxtaposed as each other's pendants on altarpiece wings, ${ }^{45}$ just as here they symmetrically flank a composition with four standing bishop saints (see below). Directly below the martyrdom of the ten thousand, the easternmost scene of the lower tier is a three-figure Crucifixion with an unidentified saint and a kneeling donor figure on the left (Fig. 14). Even if the inventor of the iconographic program did not opt for the widespread composition type combining the Crucifixion with the martyrdom of the ten thousand, the vertical juxtaposi-

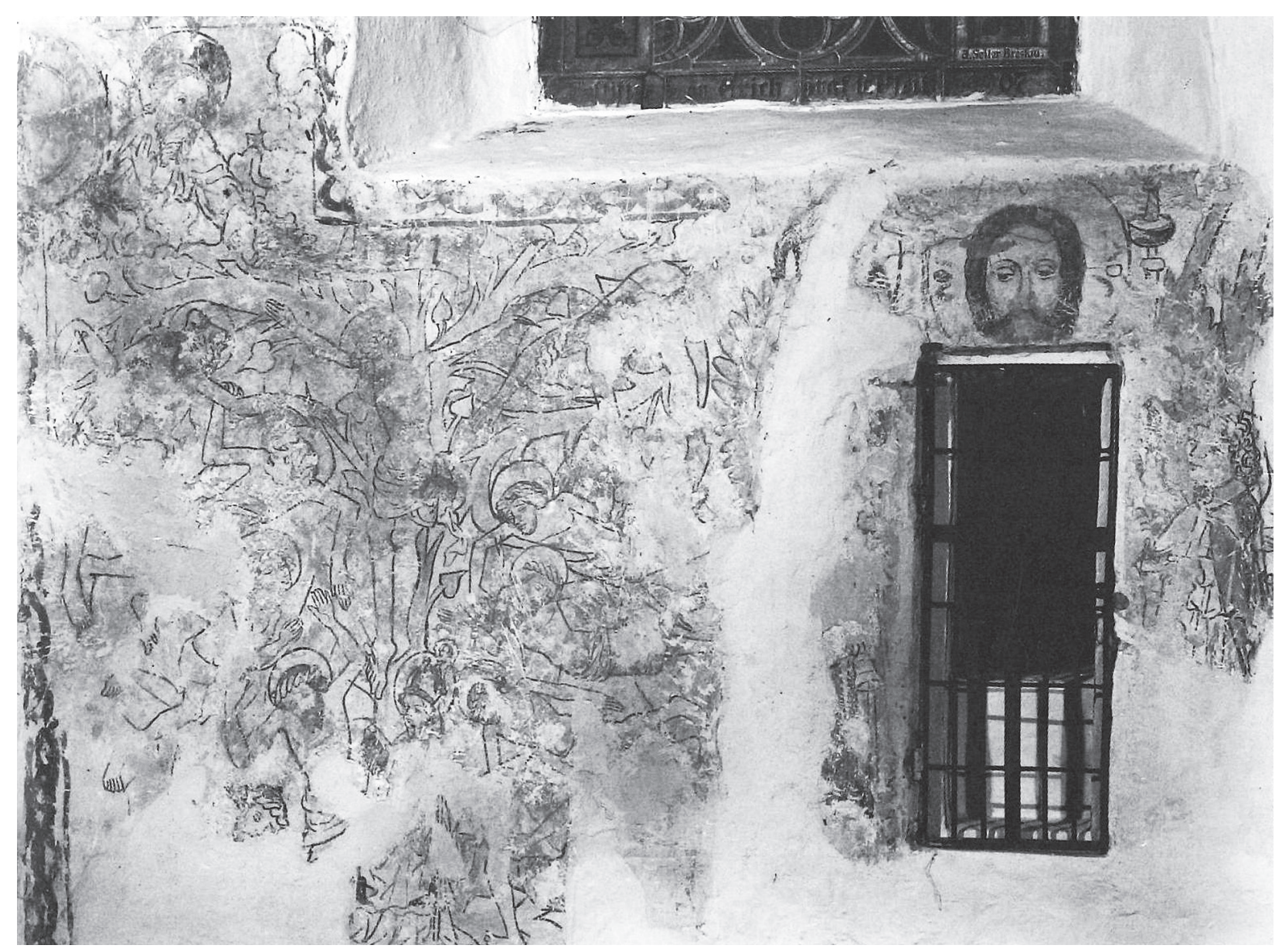

Fig. 10. Martyrdom of the Ten Thousand with the arbor vitae, Holy Face and adoring angels; Krzyzowice, church of the Assumption of the Virgin (LabUdA-SeCOMSKA, op. cit., III. Fig. 40) 
tion of the two compositions reflects a similar associative logic. Again, through the analogy of the martyrs stripped of their clothes and pierced by thorns with the figure of Christ wounded by nails, and the inclusion of the episode of the martyrs' crucifixion echoing Christ's death on the cross pictured below, the martyrs' suffering is presented as an act of imitatio Christi. In a typological interpretation, the martyrdom becomes a postfiguration ${ }^{46}$ of Christ's sacrifice - an act in the centre of the liturgy celebrated in the sanctuary, for which the wall paintings create a setting.

The second scene of the uppermost register features a row of four standing bishop saints. The composition is cut across by an eighteenth-century pilaster partially destroying the two middle figures. The first saint, similarly to the other three figures, is represented in a bishop's attire, with a mitre and a staff (Fig. 15). The lying figure at his feet identifies him as Saint Valentine. He is pointing towards the epileptic with his right hand held in a blessing gesture, in an act of healing. His second attribute is a golden monstrance, which he is holding by the knop of the shaft in his left hand.

Although the monstrance is an unusual element in the iconography of Saint Valentine, not accounted for either by his vita or his cult centred on his intercessory power for the epileptics, ${ }^{47}$ it is not unparalleled as an attribute. Valentine was similarly represented with a monstrance in a winged altarpiece from around 1515-20 originating from the parish church of Brulya (Bruiu, Braller), a village not far from Nagyszeben (Fig. 16).$^{48}$ Despite differences in the colouring and details of the clothing, or the simpler, somewhat clumsier and flatter rendering of the mural, the similarity in the posture of the saint and of the epileptic lying in front of him, ${ }^{49}$ his characteristic right hand gesture and his distinctive attribute, the monstrance, ${ }^{50}$ suggest a connection between the two works.

The common source of both compositions can be identified in a woodcut by Lucas Cranach prepared for the Wittenberger Heiltumsbuch, first published in 1509 (Fig. 17). This publication is an illustrated inventory of

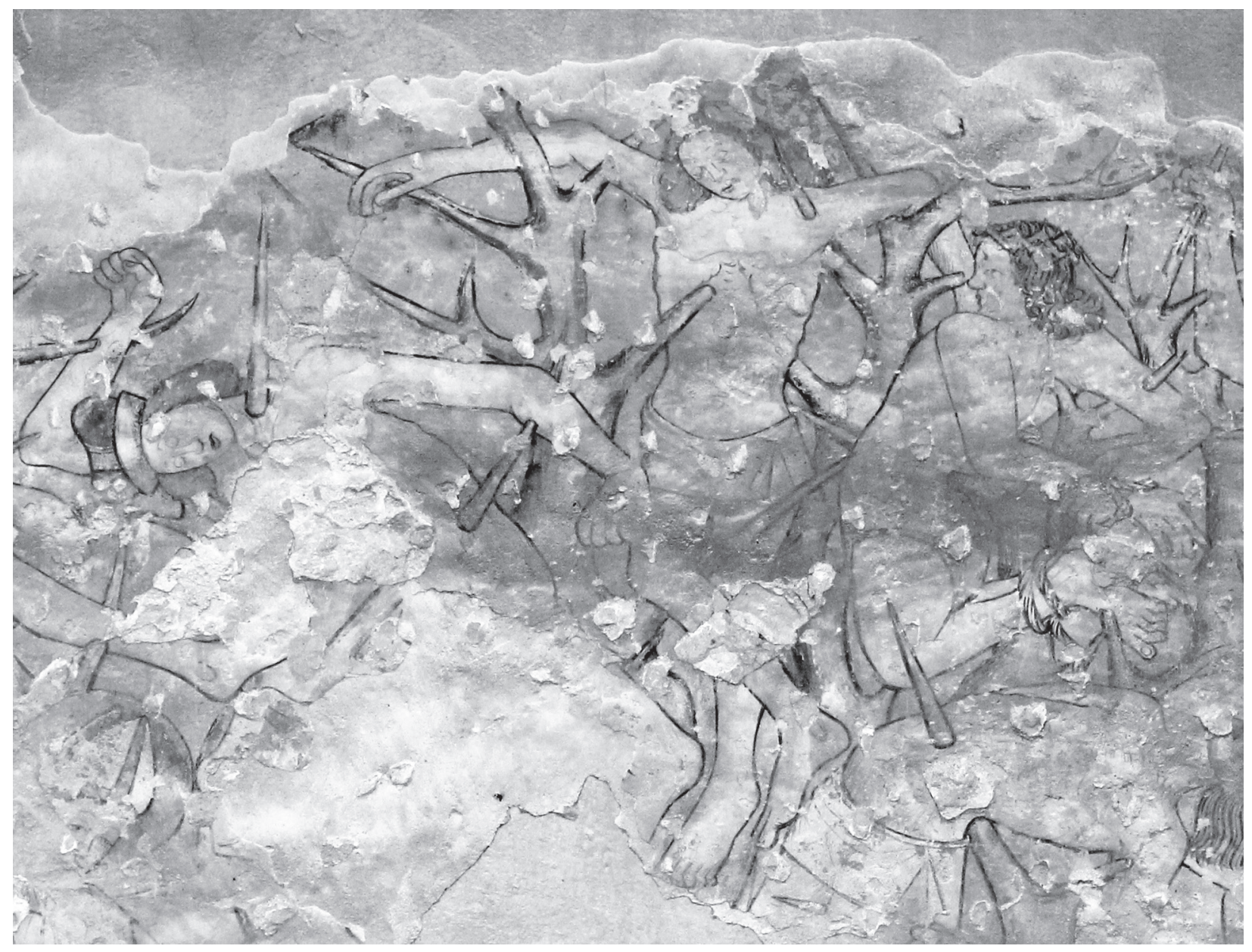

Fig. 11. Martyrdom of the Ten Thousand; Alsóbajom, parish church (detail, photo by the author). 
the reliquary collection of Elector Palatine Frederick the Wise of Saxony housed in the Schlosskirche in Wittenberg, in which the representation of the individual reliquaries are accompanied by an enumeration of their contents. ${ }^{51}$ That the woodcut of Saint Valentine is a representation of a reliquary statue is recognisable from the polygonal pedestal even if, instead of a faithful reproduction of the object, Cranach reinterpreted it in a livelier, more realistic and narrative manner. ${ }^{52}$ According to the description below the image, the monstrance held by Saint Valentine contained five particles and two whole parts of the saint's body. The presence of the monstrance is thus accounted for as a container of relics, similarly to another monstrance held by an unidentified king on fol. 4lr containing a piece of Christ's crown of thorns, and the numerous alone standing reliquary monstrances in the collection.

This reference to the reliquary function of the monstrance was nevertheless lost when the composition was transposed from the printed model into the media of panel and mural painting, in the same way as the nature of the original model - a silver reliquary statue - is no longer recognisable. In the altarpiece from Brulya, the monstrance is clearly the container of the Body of Christ, visible through the display glass in the form of the Host. Although in the mural painting in Nagyszeben its quality as a eucharistic container is not explicit, taking into consideration the connections ${ }^{53}$ between the two works, as well as their geographical closeness, it is probable that the monstrance here acquired the same eucharistic meaning when transposed from the pages of a reliquary book to the new context of a work of art decorating the sanctuary.

\section{Kolozsvár (Cluj, Klausenburg), Saint Michael's Church}

On the north-eastern wall of the southern apse of the Saint Michael's Church in Kolozsvár, a pope saint holding a golden monstrance appears besides Saint Sebastian, against a background of green hills and a cityscape, in a composition framed by a red border (Fig. 18).${ }^{54}$ The haloed pope is wearing a tiara made up of three golden crowns adorned with colourful gemstones, a red mantle, underneath a blue dalmatic with a golden lower hem, and a white alb. Beyond the display glass of the monstrance, the outlines of the Host wafer can be recognized placed in the luna; this main section is set on a six-lobed foot and is surmounted by

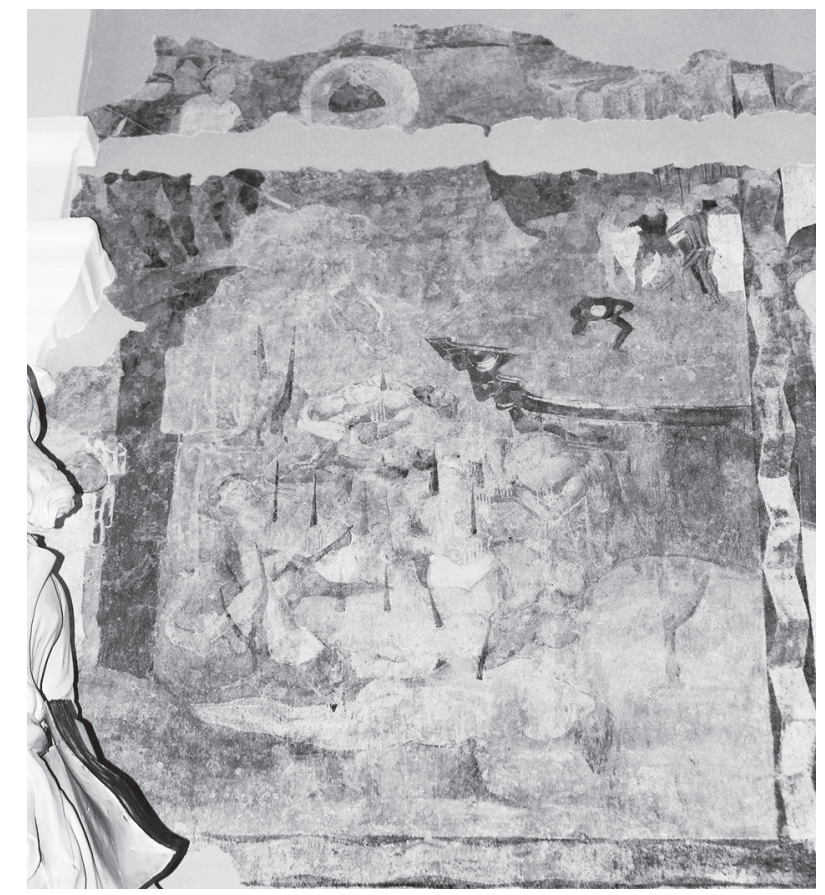

Fig. 12. Martyrdom of the Ten Thousand; Nagyszeben, former church of the Dominican nunnery (photo by the author)

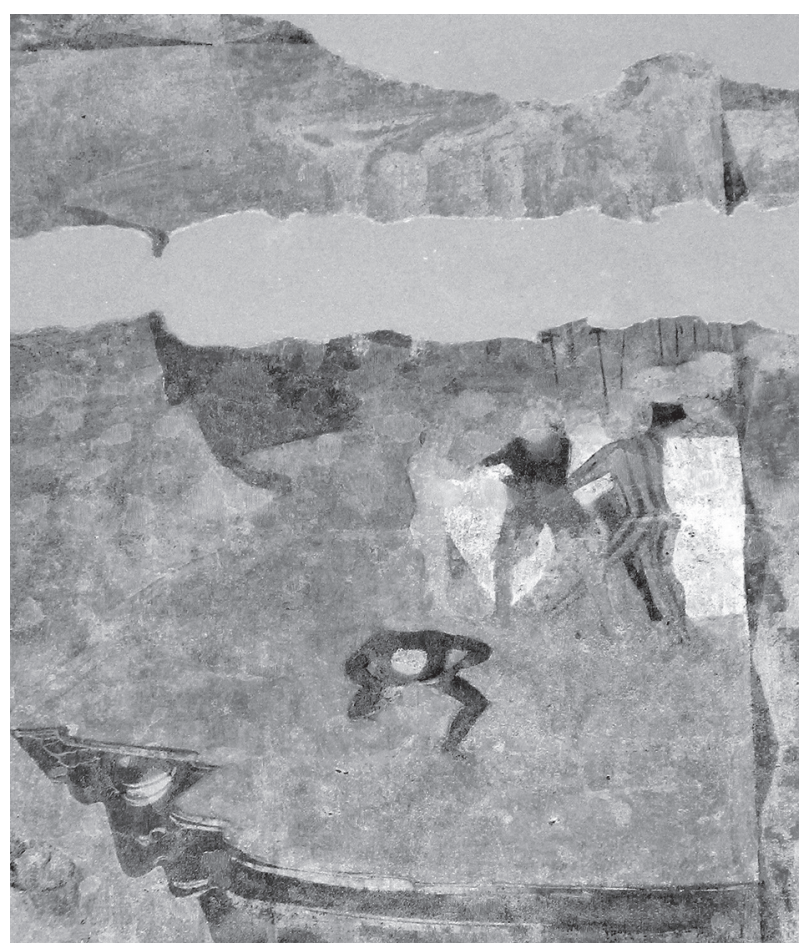

Fig. 13. The crucifixion of the martyrs; Nagyszeben, former church of the Dominican nunnery (photo by the author)

a spire and four pinnacles adorned with crockets and finials at the top (Fig. 19). On the right, Saint Sebastian appears (Fig. 20). He is represented without a halo, stripped of his clothes, tied with a rope to the tree behind him by his arms, his limbs and torso pierced 
through by arrows. He is holding a green palm leaf in his right hand.

The pope can be identified as Saint Fabian, based on his association with Sebastian. ${ }^{55}$ As the feast of both saints fell on the same day, a joint cult of the two saints had developed. Besides common dedication of churches and altars, the two saints often appear together as a pair on visual representations as well. ${ }^{56}$ In the upper part of the composition an angel is hovering in the sky, above a centrally placed hexagonal building of the cityscape. Of the angel's fragmentary figure, only details of the head, the red and green colours of his vestment, and the sword he is holding in his right hand are discernible, at the end of which a white cloth is hanging (Fig. 21).
Sebastian was one of the most popular protectors against the plague in the centuries following the Black Death. His veneration as a plague saint was based on a post-mortem miracle described in the Golden Legend, related to the plague epidemic of 680 in Rome and Pavia. In the context of his patronage, the arrows of his martyrdom also became a symbol of the plague, being associated with the arrows of divine wrath sending the epidemic as a punishment upon sinful mankind, a motif originating from the Old Testament. ${ }^{57}$

The martyred Sebastian was also an emphatically Christ-like figure. While all saintly martyrdoms can be seen as imitating the self-sacrifice of their role model, Christ, ${ }^{58}$ Sebastian's first martyrdom by arrows

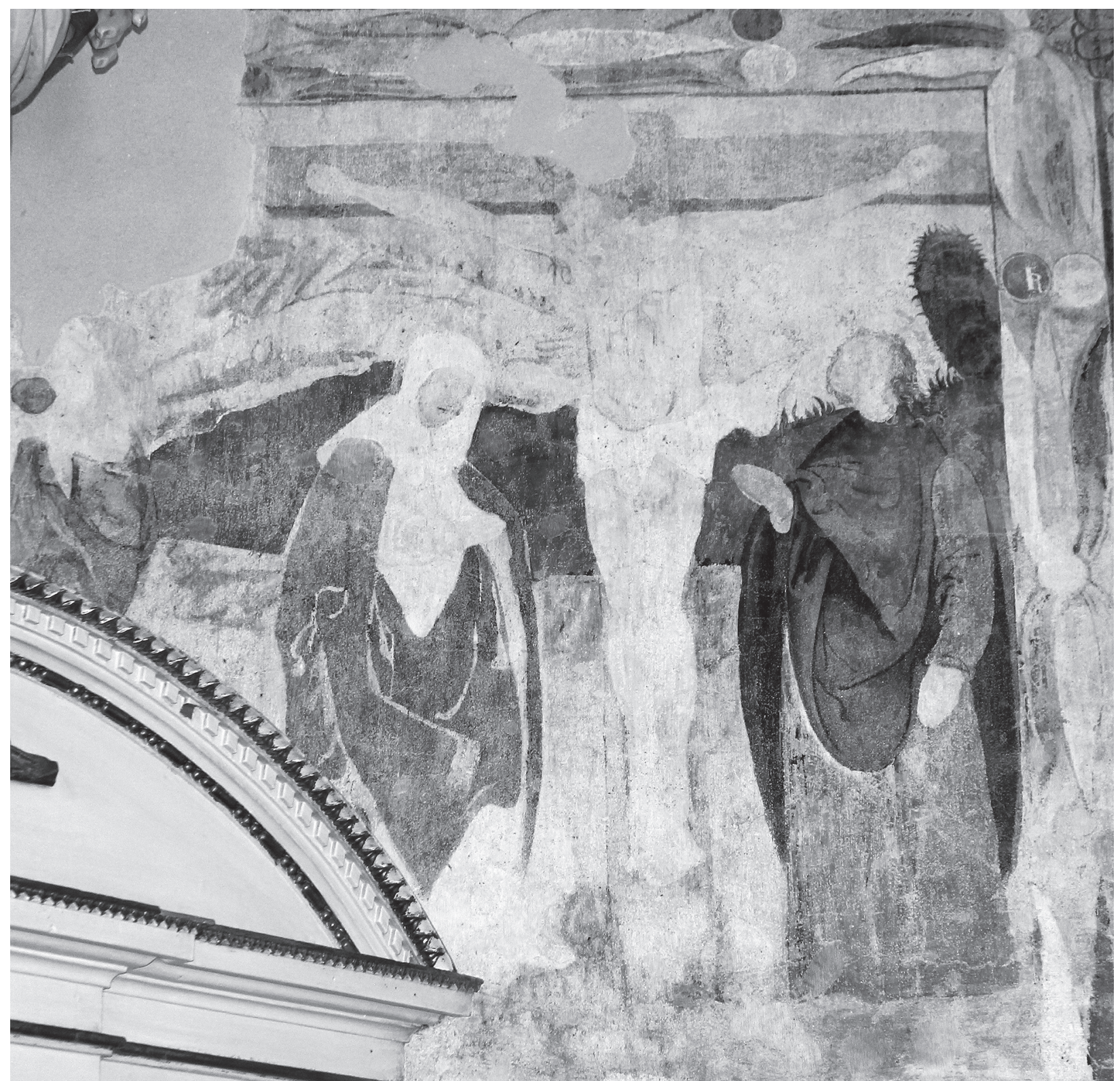

Fig. 14. Crucifixion; Nagyszeben, former church of the Dominican nunnery (photo by the author) 


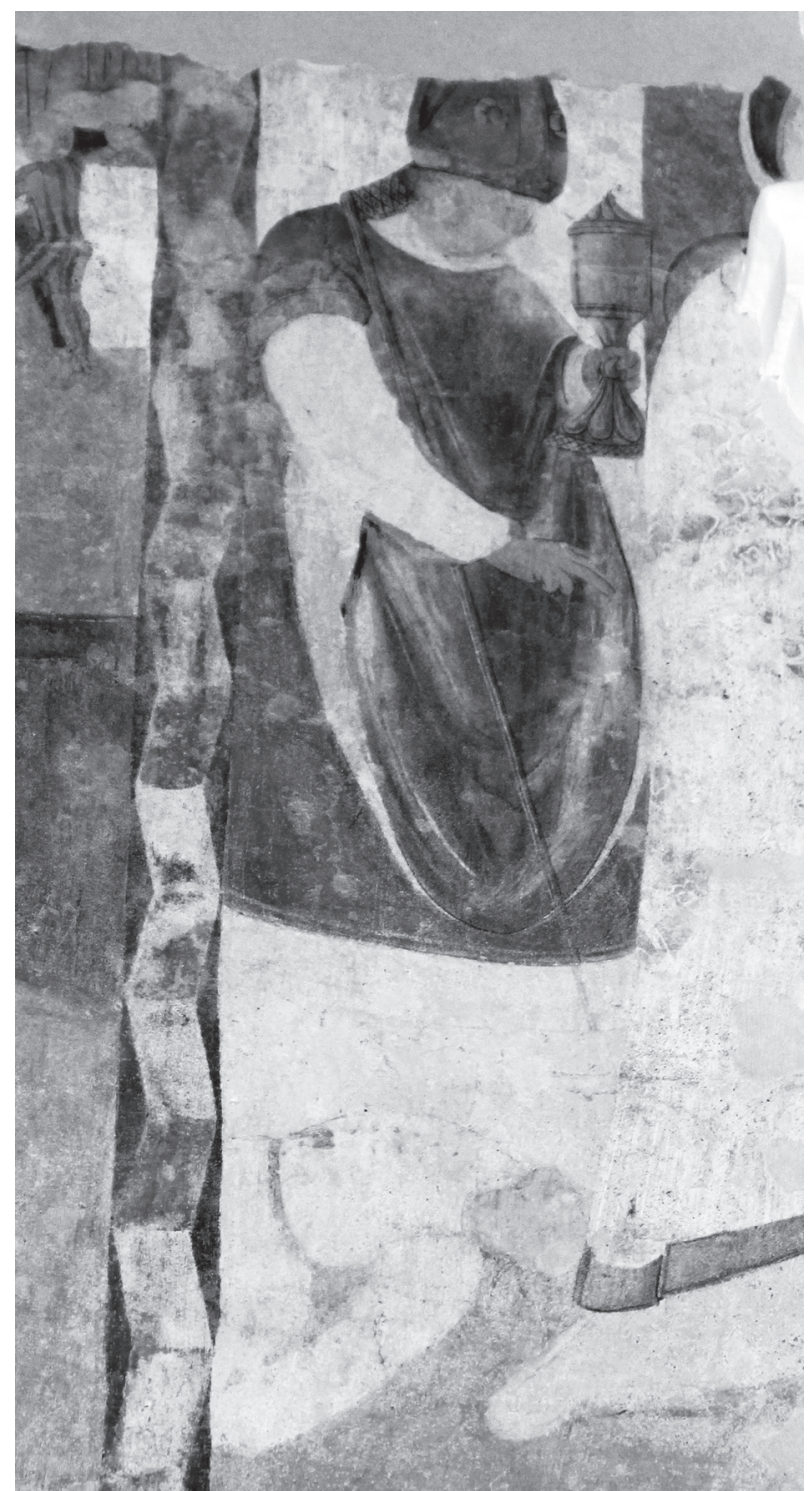

Fig.15. Saint Valentine; Nagyszeben, former church of the Dominican nunnery (photo by the author)

as related in the Golden Legend bears a closer resemblance to the Passion of Christ, as the saint, after being mortally wounded and left for dead by the soldiers, was miraculously revived by God. ${ }^{59}$ As Louise Marshall argues in a study of the saint's veneration and iconography after the Black Death, the analogy can be taken even further to the protective role of the saint, wherein Sebastian, by accepting the arrows of the plague sent by God on the people, atones for their sins through his suffering, propitiates divine anger and protects the believers from the epidemic. His martyrdom thus can be seen as a redemptive sacrifice analogous to that of Christ. ${ }^{60}$

This parallel is also reflected in visual representations. The image type of the martyred Sebastian,

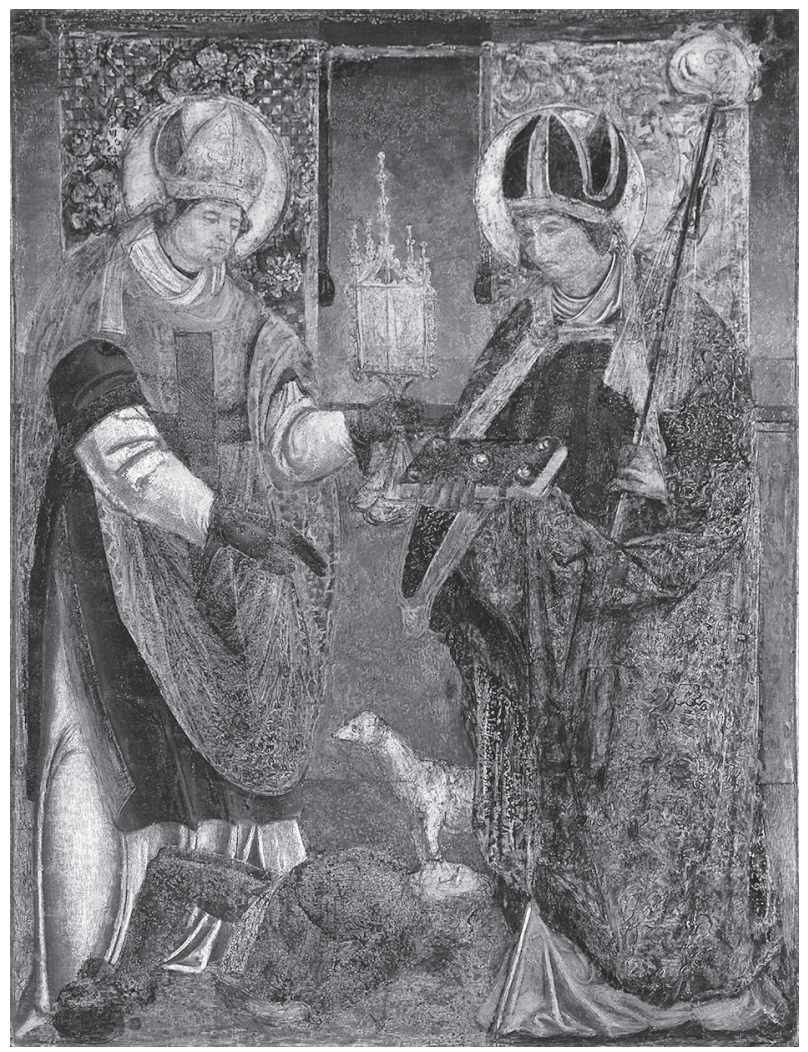

Fig. 16. Saint Valentine and an unknown bishop saint, panel of the altarpiece from Brulya (today in Nagydisznód) (photo credit: Institute for Material Culture - University of Salzburg)

tied to a tree or column by his hands, his naked body pierced by arrows, shows the influence of representations of the suffering Christ. ${ }^{61}$ This affinity is exploited in triptychs, where the tortured body of the martyred saint on one of the side panels echoes that of Christ represented in the center in an episode of the Passion or in a non-narrative devotional image evoking his suffering. ${ }^{62}$

This juxtaposition was also present in wall paintings. In a group of chapels dedicated to Saint Sebastian in south-eastern France, the figure of the patron saint appears in a central position on the eastern altar wall, his naked body bleeding from wounds being paralleled by the figure of the crucified Christ represented directly above. ${ }^{63}$ In a votive composition from the beginning of the sixteenth century in the southern aisle of the church of Unsere Liebe Frau in Vill (South Tyrol), featuring donor figures below a row of helping saints, the two major plague saints, Sebastian and Roch, flank the figure of the eucharistic Man of Sorrows holding a chalice. In an imitation of Christ, both saints appear naked but for their loincloths, covered with wounds - by arrows and the 


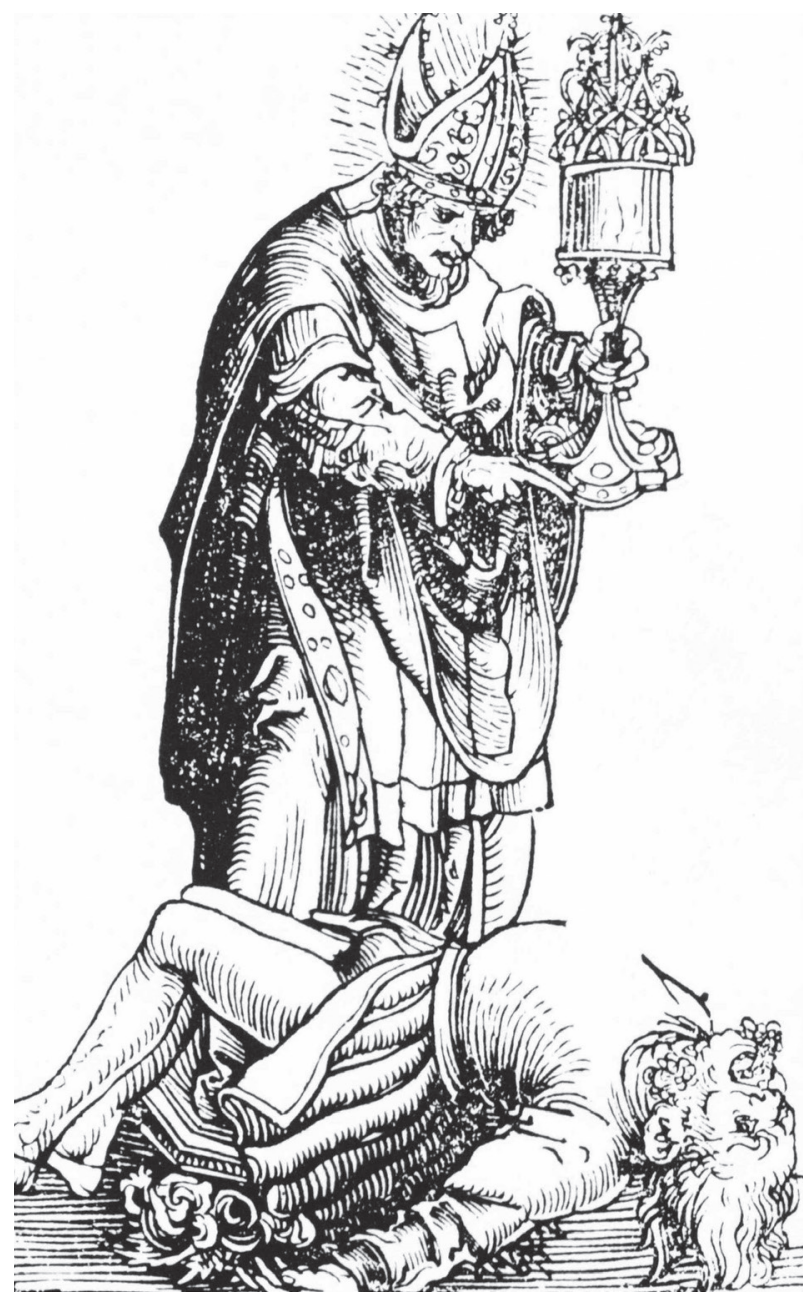

Fig. 17. Lucas Cranach: Saint Valentine; Wittenberger Heiltumsbuch, Wittenberg 1509, fol. 20v.

plague, respectively - that they display to intercede for the donor family on account of their suffering (Fig. 22). ${ }^{64}$

The martyrdom of Saint Sebastian was in several cases represented in the sanctuary, in the vicinity of eucharistic themes. On the northern sanctuary wall of the parish church in Schöder (Austria), the wall section above the sacrament niche is decorated with compositions related to the celebration of the eucharistic liturgy: angels with candles and the Crucifixion. These scenes are flanked on the left by the figures of two standing saints, whose representation in this context has eucharistic overtones: Saint John the Evangelist with a chalice ${ }^{65}$ and, above, an emphatically Christlike Saint Sebastian, captured not in the moment of his martyrdom with the usual arrows, but in a posture reminiscent of the Man of Sorrows, wearing a red mantle, covered with bleeding wounds, and pointing to his side wound (Fig. 23). ${ }^{66}$

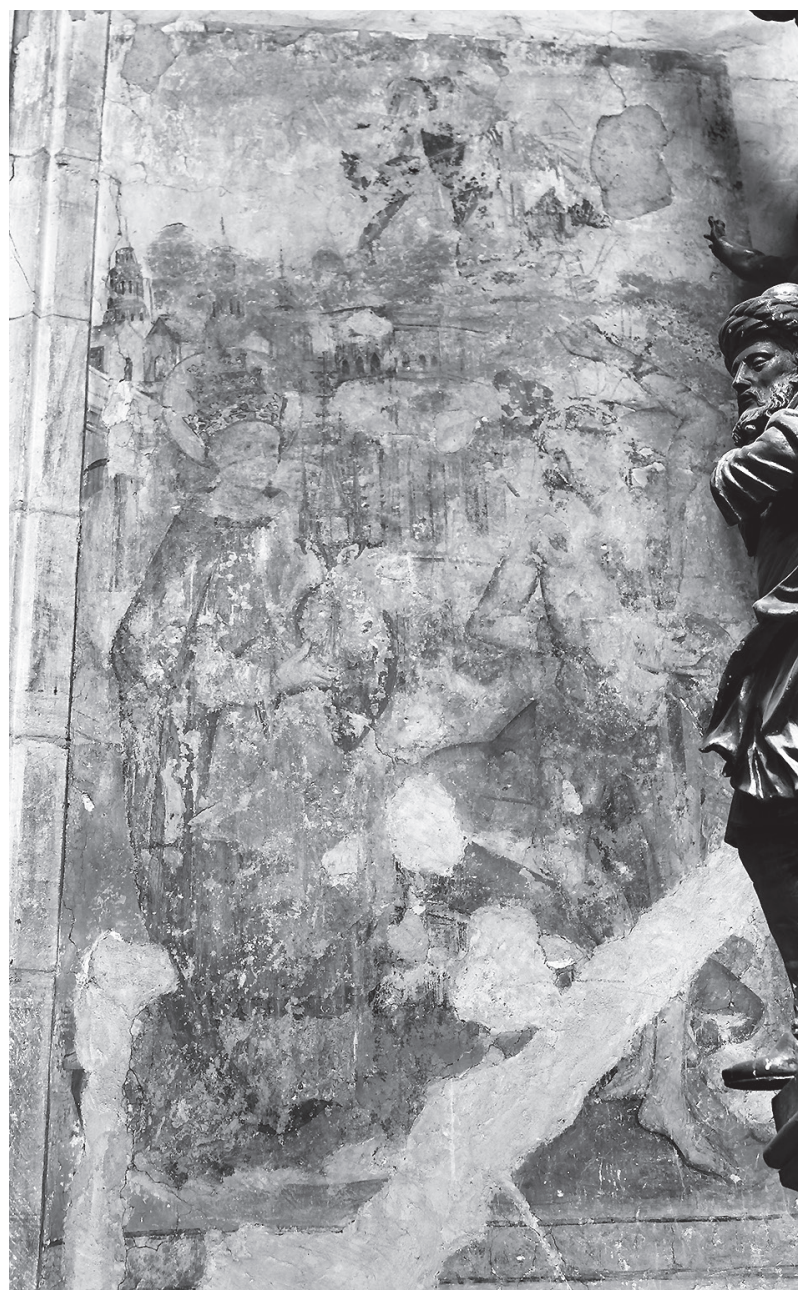

Fig. 18. Saint Fabian and Saint Sebastian; Kolozsvár, Saint Michael's Church (photo by the author)

The posture of Saint Sebastian in the mural in Kolozsvár is reminiscent of that of Christ in contemporary Flagellation scenes. ${ }^{67}$ While it is possible that, as in the examples mentioned above, the figure of Sebastian was juxtaposed as a visual analogy to a representation of the suffering Christ either on the eastern wall of the southern apse, or on an altarpiece, we have no other evidence about the contemporary decoration of the side chapel to support this hypothesis.

Although there is no element in his vita that would qualify him as a plague saint, Pope Fabian, due to his association with Sebastian based on the shared feast day, also came to share the status of the latter as a protector against the pestilence. ${ }^{68}$ In this way, he was invoked together with Saint Sebastian in votive masses and prayers against the plague ${ }^{69}$ and was also included in compositions where Sebastian was represented with other plague saints, especially the trio of Saint Sebastian, Fabian and Roch was frequent. ${ }^{70}$ 


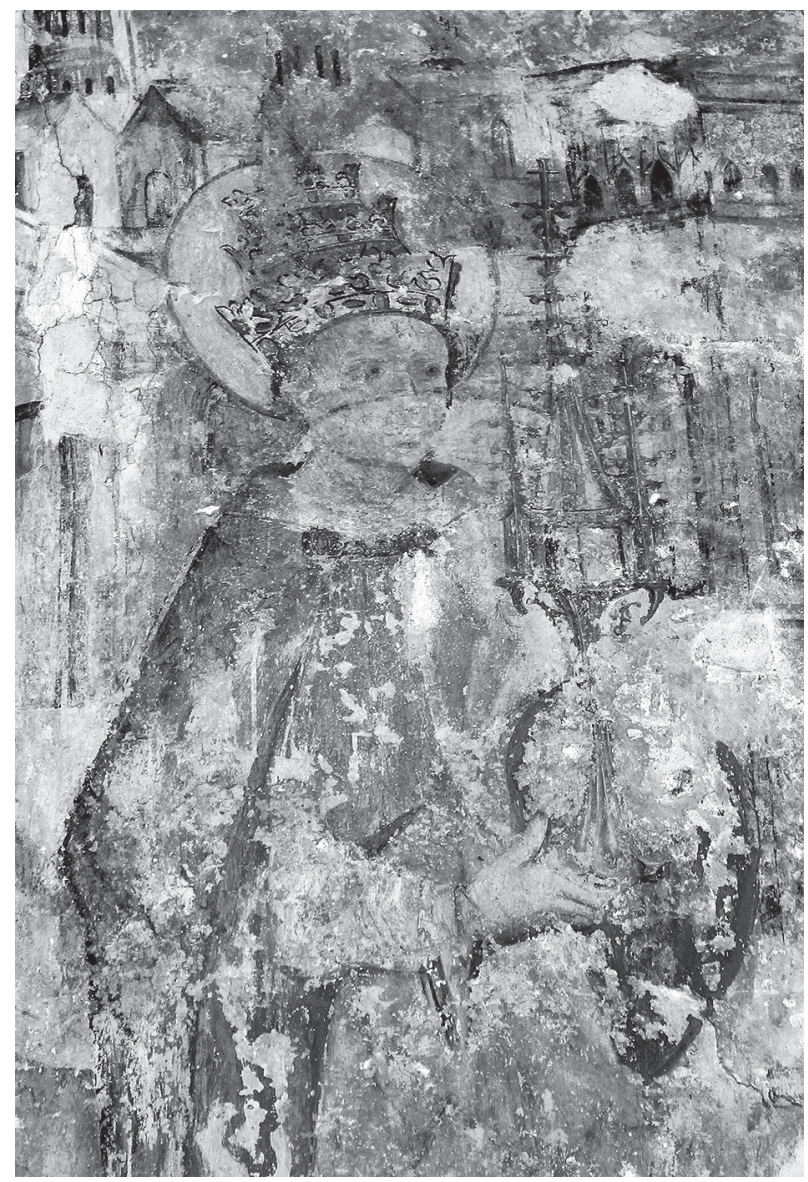

Fig. 19. Saint Fabian, Kolozsvár; Saint Michael's Church (photo by the author)

What is peculiar about his representation in Kolozsvar is the monstrance, which is not among the conventional attributes of the saint, who is usually represented with a sword (the instrument of his martyrdom), a book or a papal cross. ${ }^{71}$ Pope Fabian was known throughout the middle ages as the author of a number of decrees ${ }^{72}$ containing regulations on the celebration of the eucharistic liturgy as well as the frequency of lay communion. Although these regulations were often referred to in works of medieval canon law, ${ }^{73}$ this concern with the Blessed Sacrament attributed to the pope apparently did not have an effect on his iconography.

While it seems unparalleled as an attribute of Saint Fabian, the Eucharist was a recurring motif of plague iconography. ${ }^{74}$ As plague had traditionally been considered a punishment by God for the sins of mankind, protection and healing was also primarily sought after by devotional means. Besides prayers and saintly intercession, the sacraments, and, foremost, penance and the Eucharist, played an important role in pacifying divine anger. ${ }^{75}$ In contemporary medical

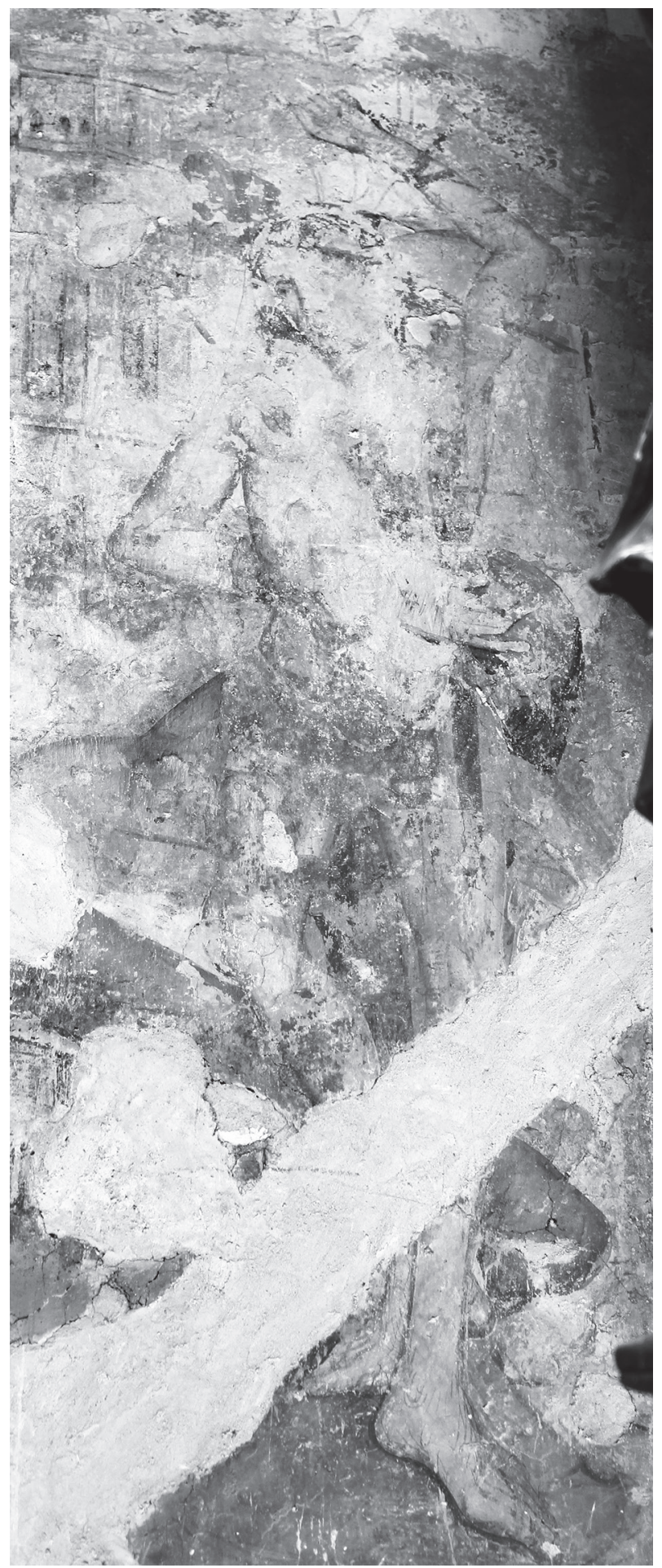

Fig. 20. Saint Sebastian; Kolozsvár, Saint Michael's Church (photo by the author)

works, the last rites, among them the administration of "the most delightful and precious medicine: the body of our lord and saviour Jesus Christ" 76 were explicitly recommended for plague victims as the most efficient treatment, not so much with the prospect of physical healing, but for the salvation of the soul of the dying. ${ }^{77}$ 
The importance of the last rites for a good death is a recurring motif in visual representations of the plague as well. In a panel depicting a plague miracle of Saint Nicholas of Tolentino by Giovanni di Paolo (1457), a priest is carrying the viaticum in a Gothic monstrance to the dying person (Fig. 24). ${ }^{78}$ In a woodcut serving as the title page of a plague treatise by Philipp Culmacher von Eger $^{79}$ the representation of God, a plague angel and a skeletal personification of death in the central axis suggest the divine origin of the epidemic, while on both sides of the composition the different means of protection appear: interceding plague saints and praying people on the left, and a priest with a host delivering last communion to a person on his deathbed and a Pietà on the right (Fig. 25). Besides stressing the importance of the last Sacrament, the juxtaposition of the Body of Christ in the form of the Host and his dead body held by the Virgin Mary above suggests that through the Eucharist one can share in the expiatory sacrifice of Christ, and thus hope for a reconciliation with a wrathful, punishing God. ${ }^{80}$

The Eucharist can also appear as a requisite of penitential processions, which were another means of appeasing divine wrath. ${ }^{81}$ An example for this is a double-folio representation of the procession of Saint Gregory the Great in the Très Riches Heures du Duc de Berry, ${ }^{82}$ where in addition to the image of the Virgin on a banner, the Eucharist is carried around in a monstrance in the hope of averting the plague that was raging in Rome in 590. It appears that, even if it is difficult to convincingly account for the presence of the monstrance as a personal attribute of Saint Fabian, being a common motif of late medieval plague iconography, it fits in with the general message of the composition centred around seeking heavenly protection from the deadly disease.

Angels appear in plague related narratives in the Old Testament, as well as in the legends of saints, as heralds of divine wrath or remission. ${ }^{83}$ A good angel followed by a bad angel carrying a spear also appears in the plague miracle included in Saint Sebastian's vita. ${ }^{84}$ The textual base for the representation in Kolozsvar, however, is most likely not this legend, but the vision of Saint Gregory the Great, who, when leading an expiatory procession at the time of the plague ravaging in Rome, saw an angel on the top of the Castel Sant'Angelo wiping a bloody sword and sheathing it, a gesture which had signalled the end of the plague. ${ }^{85}$ Sworded plague angels also occur in representations unrelated to this episode of Saint Gregory's legend (Fig. 25), ${ }^{86}$ this is also the case of the mural in Kolozs-

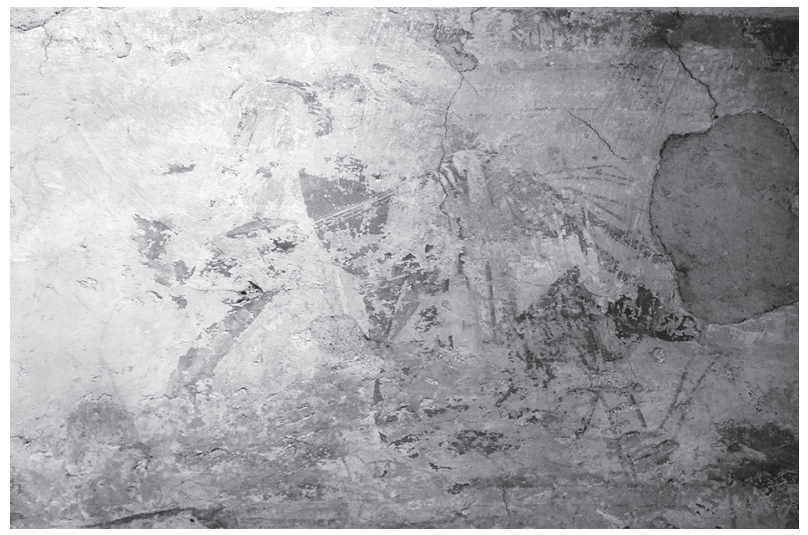

Fig. 21. Plague angel; Kolozsvár, Saint Michael's Church (photo by the author)

vár. The angel here is not a threatening symbol of divine wrath and of the violence of the epidemic, but, wiping the sword with a white cloth, indicates a positive outcome of appeasing God and the ceasing of the plague as a result of the saintly intercession.

Based on graphic models and stylistic features, the mural can be dated to the last two decades of the fifteenth century. According to the research of István Szabó, in the last quarter of the fifteenth century eight years were marked by plague in the territory of medieval Hungary. While the exact territorial extension is in most cases unknown, sources suggest that the epidemics of 1480 and 1495 were the most devastating, extending from the western borders up to the southeastern territory of the Transylvanian Burzenland. ${ }^{87}$ Even if, with no exact dating, the commission of the mural cannot be connected to a specific outbreak, historical data about contemporary epidemics is consistent with the interpretation of the mural in suggesting that protection against the plague was a very topical concern at the time.

\section{Székelydálya (Daia)}

On the northern sanctuary wall of the parish church in Székelydálya, the representation of a ship fills the easternmost lunette-shaped field below the vaulting (end of the fifteenth century, Fig. 26). A large crowd of people of both genders and of various ages and social groups are standing in the ship in several rows, all unhaloed. In the front rows, mostly female figures - women and children - can be seen wearing crowns or white veils. In front of the crowd, a now damaged female figure with long wavy hair, wearing a crown and a red mantle is standing, rising above the other figures. To her right 

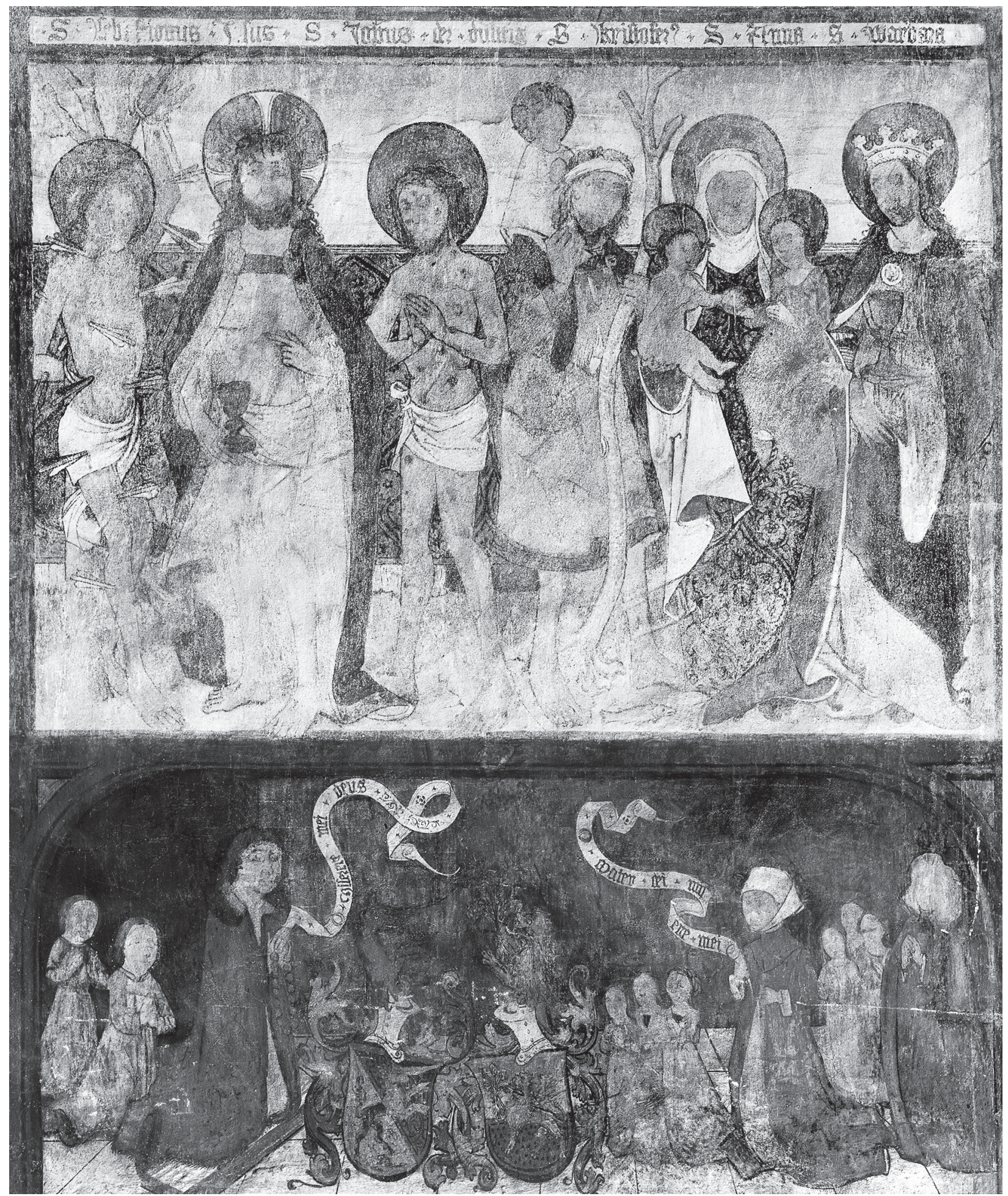

Fig. 22. Votive composition with Christ as the Man of Sorrows, Mantle Madonna and saints; Vill, South Tyrol (photo credit: Institute for Material Culture - University of Salzburg)

is a bishop in an ornate mitre; the figure of a pope with a tiara next to him, visible on the watercolour copy, ${ }^{88}$ is now more damaged and hardly recognisable. All the people are depicted in half profile turning to the right, their hands raised in a gesture of prayer. In the upper part of the mast below the crow's nest, there is a threefigure Crucifixion scene set against the background of the sail (Fig. 27). The crucified Christ is flanked by the standing figures of Saint John the Evangelist and the Virgin Mary, who are turning towards him in prayer. 


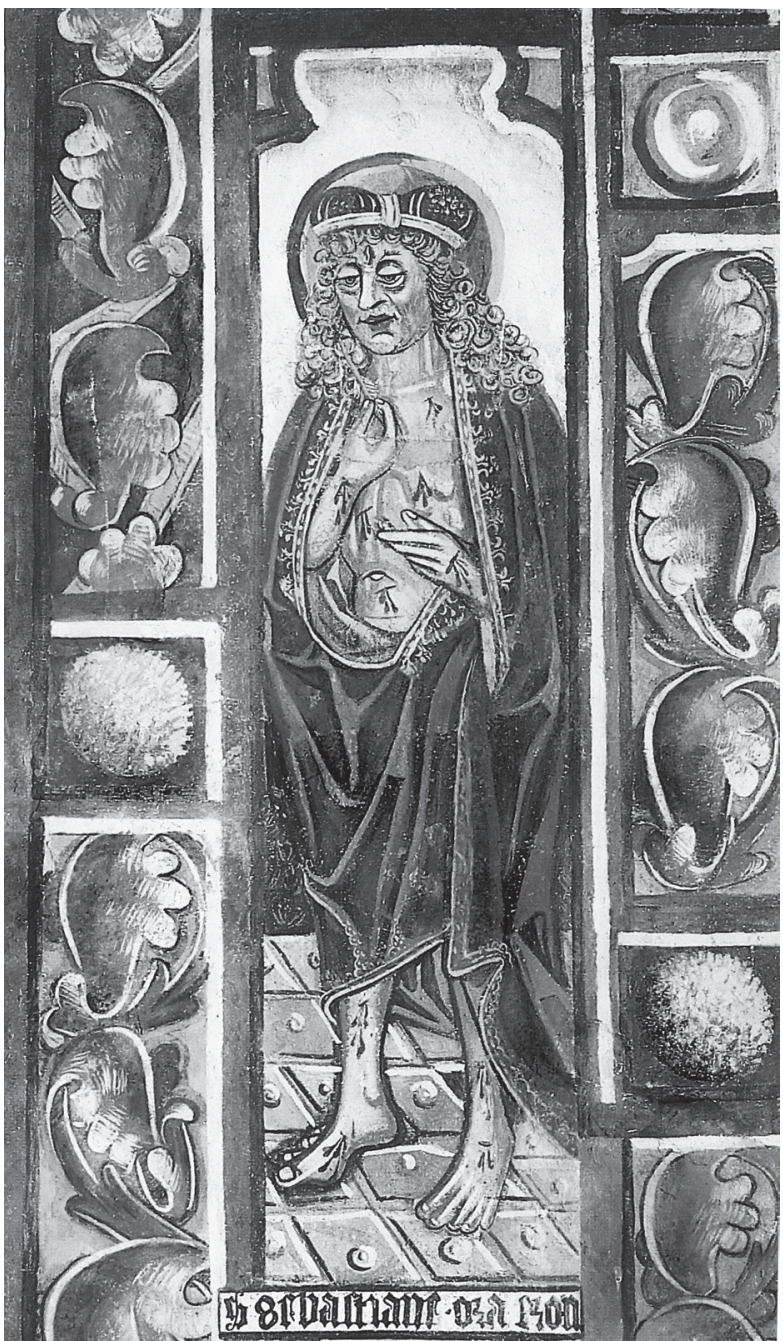

Fig. 23. Saint Sebastian; Schöder (Austria), parish church (GobIET, op. cit., Farbtafel X.)

The horizontal bar of the dark brown cross bearing a titulus is bent downwards in a bow shape. Above the crowd, to the right from the mast, there is a group of six men. Several of them are wearing armour, the first one is holding a long wooden stick in his right hand. ${ }^{89}$ Behind the group there is a portal painted in various colours resembling a rainbow, with a stone building on the other side.

The scene has been variously identified as an episode from the legend of Saint Margaret ${ }^{90}$ or Saint Ursula, ${ }^{91}$ part of a Last Judgment scene, ${ }^{92}$ while in most of the recent literature it is described as a representation of the Ship of the Church..$^{93}$ Although the composition bears a resemblance with allegorical representations of the Church as a ship, considering all iconographic features, an identification as the martyrdom of Saint Ursula and the eleven thousand virgins is more plausible.

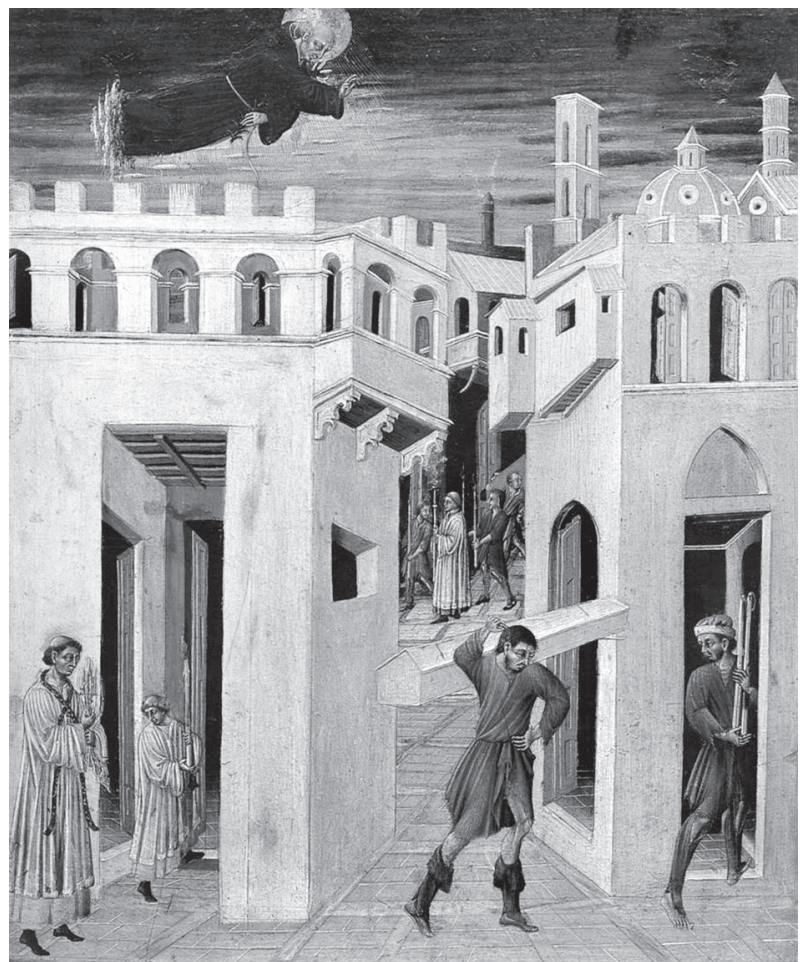

Fig. 24. Giovanni di Paolo: Panel from the life of Saint Nicholas of Tolentino; Vienna, Akademie der bildenden Künste (Marshall, op. cit. 2013, Fig. 1)

The motif of the soldier standing in front of the ship to the right, raising a sword above his head, ready to behead a woman whom he is pulling by her hair over the edge of the boat, is a typical element of the martyrdom of Saint Ursula scenes, with close compositional analogies in the period. ${ }^{94}$ The maiden princess standing in front of the crowd is most probably the protagonist of the legend, Saint Ursula, emphasized through her position and larger size, similar to several other representations of the martyrdom scene. The composition of the praying crowd in the boat also corresponds to the written legendary tradition, which describes that the virgins were accompanied by several men - pope Cyriacus and a number of bishops among them - and some married women. On the other hand, the large proportion of female figures would be unusual on a representation of the Ship of the Church. The group of soldiers approaching from the right on the shore behind the boat can be interpreted as the Huns attacking Saint Ursula and her retinue when arriving back from Rome to Cologne. The cityscape of Cologne surrounded with the city walls and gates often appears in the background of the martyrdom scene, ${ }^{95}$ the portal with the portion of a stone wall behind the soldiers is most probably a simplified reference to the town. 


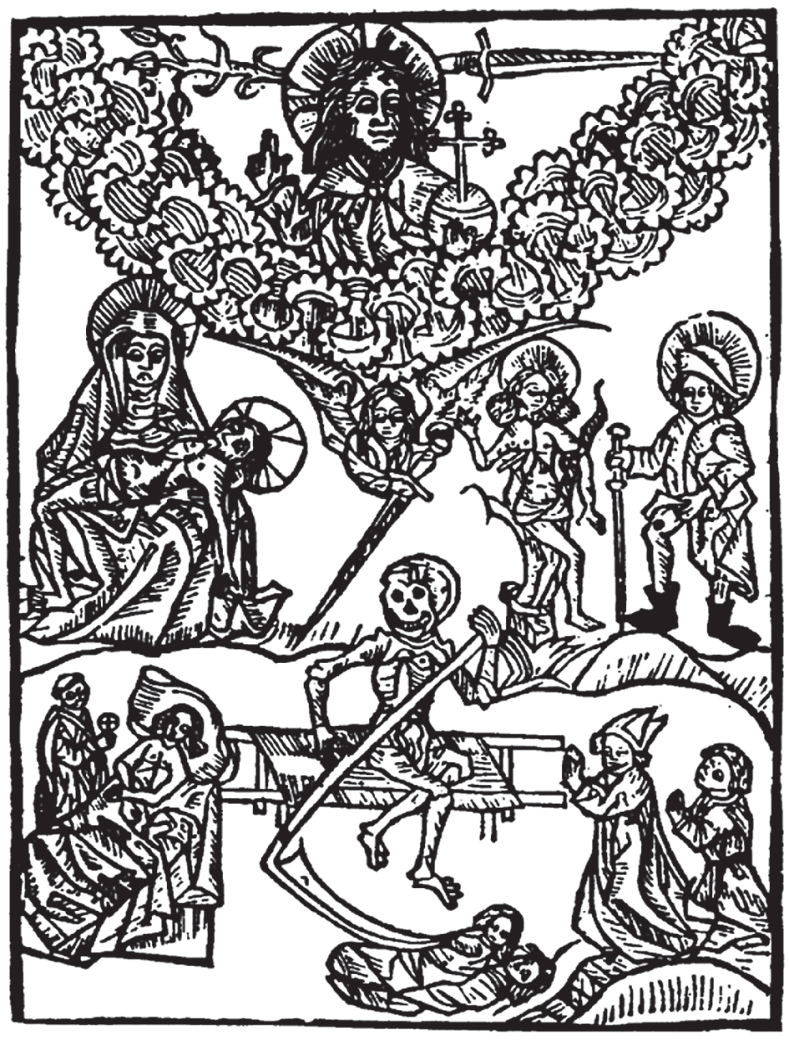

Fig. 25. Philipp Culmacher von Eger, Regimen wider die Pestilenz, title page (BOECKL, op. cit., Fig. 4.7)

According to the legend, the chief of the Huns shot Ursula with an arrow. It is not specified, however, how the members of her retinue met their death. Although archers standing on the shore aiming at the virgins appear in most representations of the scene, there are cases where - as in Székelydálya - there are no archers among the Huns, who are equipped with swords and lances instead. ${ }^{96}$

The motif which would best support an identification of the scene as the Ship of the Church is the Crucifixion appearing in front of the sail. Indeed, there are no references to it in the written versions of the legend of Saint Ursula. ${ }^{97}$ Instead, the motif has its origins in the allegory of the Church as a ship with Christ's cross as its mast, on board of which Christian believers could avoid the deadly perils of temptation on the voyage toward the harbour of eternal life. ${ }^{98}$ This ship imagery, elaborated by early Christian authors, was flourishing in the fifteenth and sixteenth centuries, ${ }^{99}$ as several contemporary visual representations attest. ${ }^{100}$

However, this is not the only case where the motif of the crucified Christ on the ship's mast appears in Saint Ursula's iconography. In an allegorical composition type used in publications connected to Saint Ursula confraternities, the ship of Saint Ursula is presented as

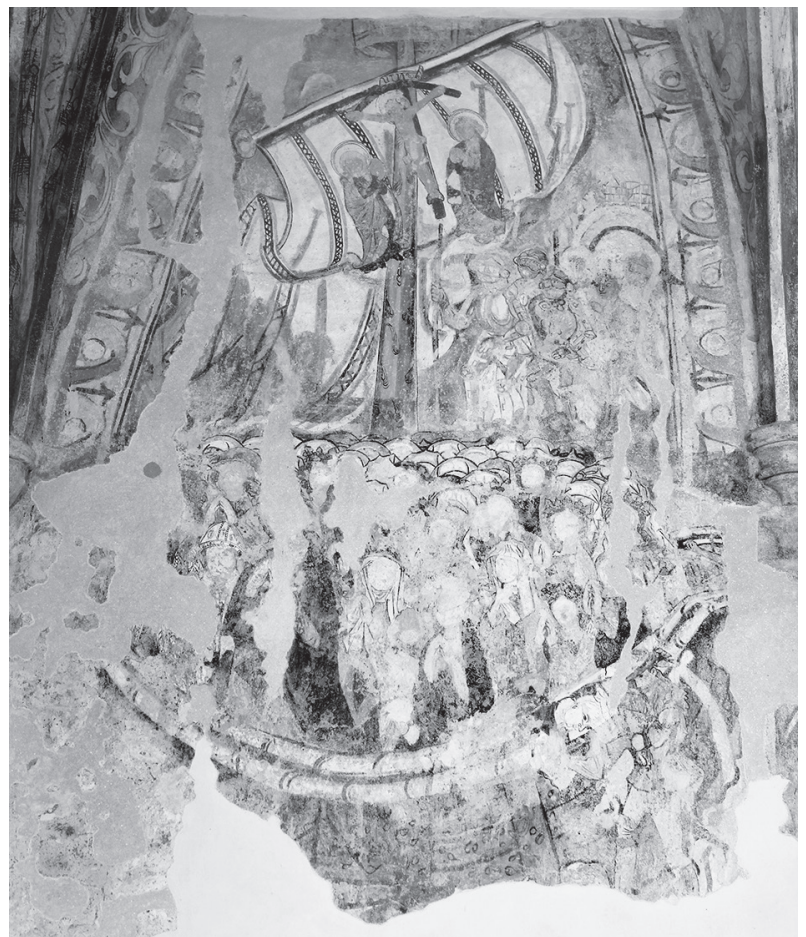

Fig. 26. The martyrdom of Saint Ursula and the eleven thousand virgins; Székelydálya, parish church (photo by the author)

the Ship of Faith, carrying the members of the brotherhood to salvation. A woodcut decorating the title page of the confraternity book from Strassbourg (1497) ${ }^{101}$ combines all the pious means deployed by the members of the brotherhood to secure the salvation of the soul (Fig. 28). Christ's salvific sacrifice, visualised by the figure of Christ crucified on the cross-shaped mast is repeated on the right, in a scene of a priest celebrating Mass, an act which has as its immediate effect the salvation of a soul from Purgatory. Below, at the foot of the cross, there is an altar table with the Eucharist in both species, around which a group of saints are gathered, with the figure of the Virgin Mary with the Infant Christ in the centre, and Saint Ursula on her right. Before the altar, Saint John the Evangelist is collecting Christ's blood securing eternal life streaming from the fons vitae into his chalice. Christ's expiatory sacrifice, his body and blood in the Sacrament, the intercession of the saints, and prominently that of Saint Ursula on account of her merits and martyr's death, all work toward the propitiation of God and secure salvation for the ship's passengers.

The image of the crucified Christ on the ship's mast could also feature in narrative representations of the martyrdom scene, as in the case of Székelydálya, 


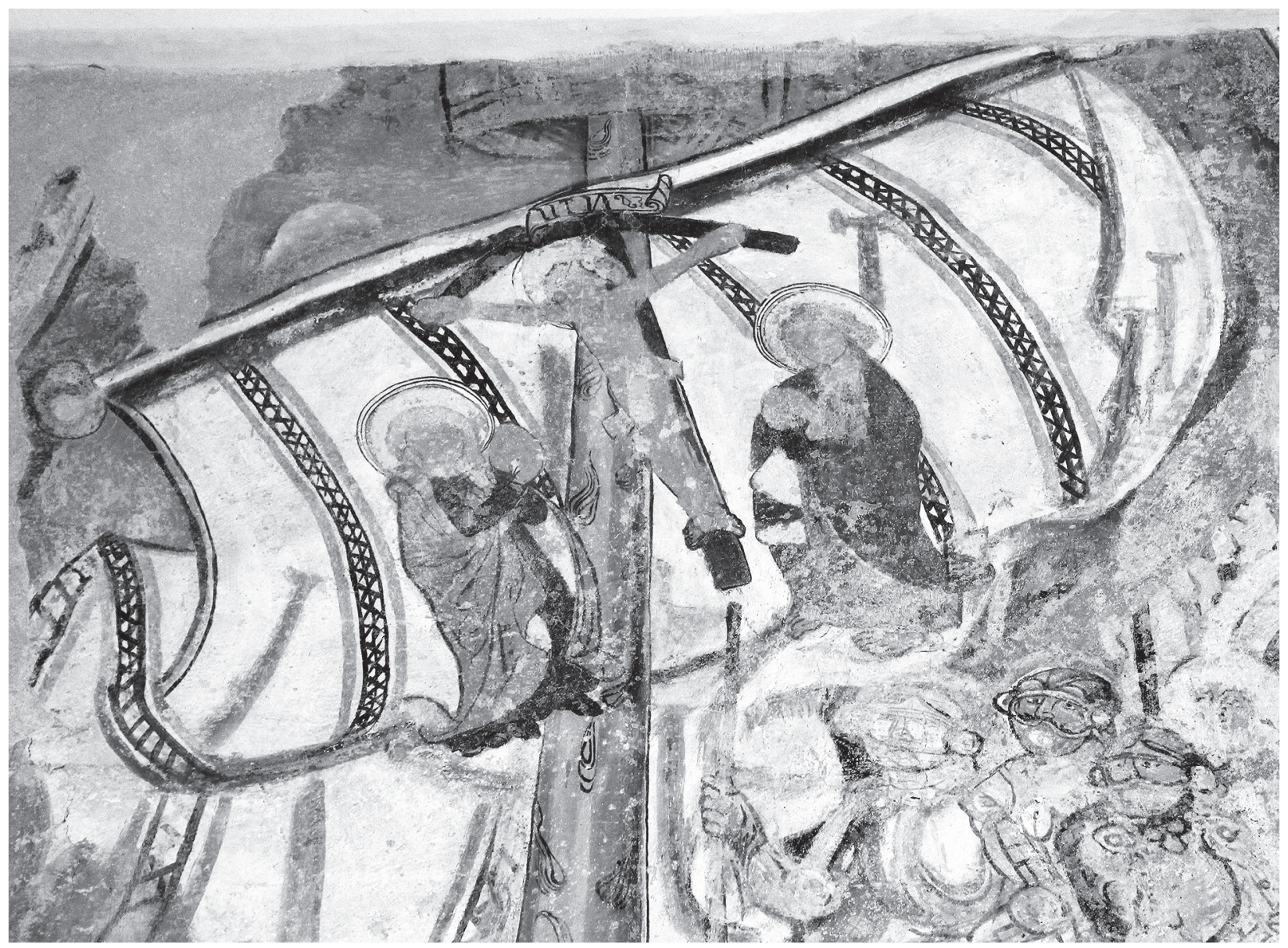

Fig. 27. The Crucifixion; Székelydálya, parish church (photo by the author)

although this was less common. On a panel of an altarpiece from the Cistercian nunnery of Lichtental (Germany) from 1496, two crucifixes of identical design and dimension (considerably smaller than those in the allegorical representations) appear: one on the top of the column-like mast of the ship, and one which Saint Ursula is holding up in her hand (Fig. 29). ${ }^{102}$ The presence of the crosses is justified by her words visualized in the form of a curling inscription scroll, ${ }^{103}$ encouraging members of her retinue to fight bravely in Christ's cross, as eternal life will follow the cruel death brought upon them. On the central panel of Jörg Breu the Elder's Saint Ursula altarpiece (c. 1520-30), ${ }^{104}$ the mast of Saint Ursula's ship is replaced by a life-size figure of Christ on the cross, encompassed in a rainbowlike halo, creating a devotional focal point within the populous, stirring martyrdom scene.

The above examples show that the incorporation of the Crucifixion into a representation of Saint Ursula's martyrdom is not an iconographic oddity, but an iconographic feature fitting well into contemporary developments in the devotion to the saint and the representation of the theme. ${ }^{105}$ This motif prompts a more comprehensive interpretation where the ship, beyond being the vessel carrying Saint Ursula and her retinue to meet their fate under the walls of Cologne, on another level also evokes the idea of the Ship of the Church, in which the community of believers make their journey through life and death under the protection of the Cross - an image which at the same time also resonates with the liturgy celebrated in the sanctuary centred on a reiteration of Christ's redeeming sacrifice.

The Body of Christ is even more emphatically the focal point of the fragmentarily surviving wall painting decoration of the sacramental niche on the northeastern sanctuary wall (Fig. 30). ${ }^{106}$ Above the ogeearched niche, Saint Veronica is standing before a stone wall, holding up her veil with the Holy Face. Below, the upper bodies of two haloed saints survive, who are turning towards the sacrament niche, their hands raised in a gesture of prayer. The figure on the left can be identified as Saint Peter, based on the fragmentary object resting against his shoulder, the surviving upper 


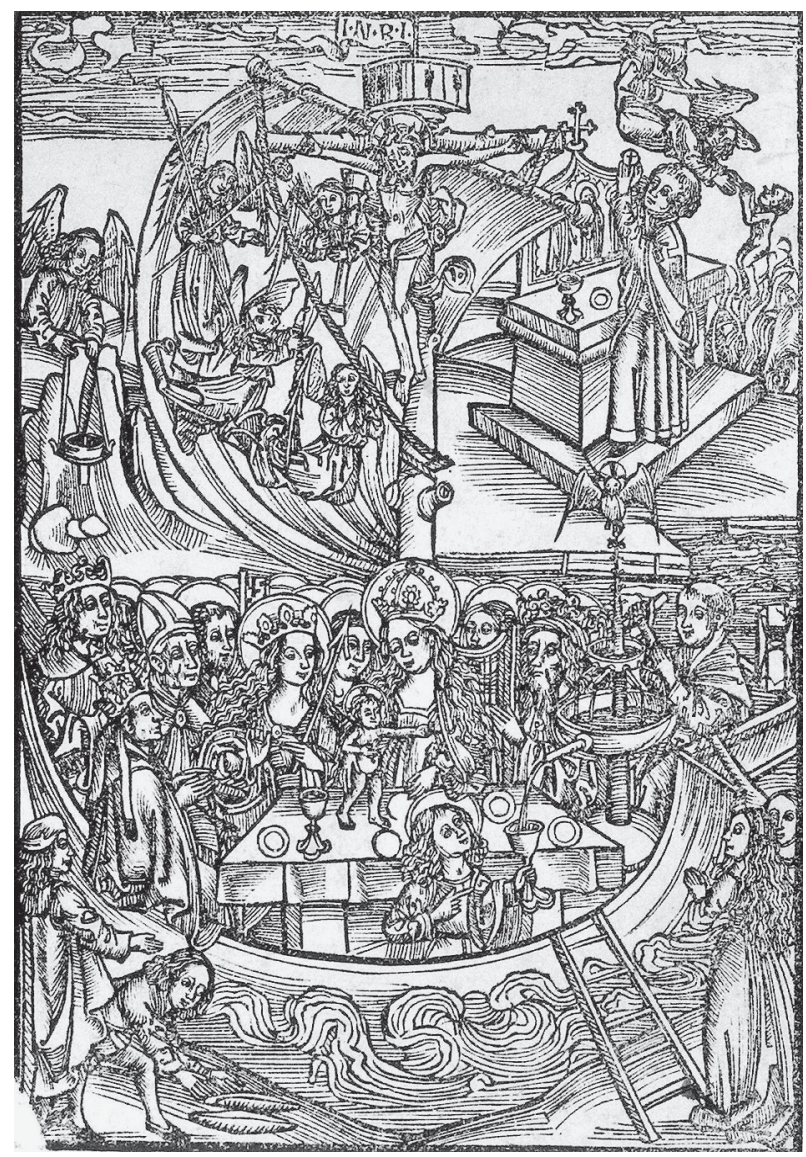

Fig. 28. Bartholomäus Kistler: Von Sant Ursulen schifflin; Berlin, Staatsbibliothek, Preußischer Kulturbesitz, Inkunabelsammlung (DEKIERT, op. cit., Fig. 228)

part of which resembles the shaft and bit of a key; the other saint is thus most probably Saint Paul. ${ }^{107}$

The Veil of Veronica, along with the heads of both apostle princes Peter and Paul, counted among the most precious relics of Rome, ${ }^{108}$ which attracted masses of pilgrims to the Eternal City in the hope of indulgences. The image of the Sudarium flanked by Saint Peter and Saint Paul (with or without the figure of Saint Veronica herself) thus has pilgrimage associations, ${ }^{109}$ and was spread by pilgrim badges from the fourteenth century onwards, and by prints later on. ${ }^{110}$ In Transylvania several examples of this type are known on pilgrimage badges or coins reused in the decoration of bells in the second half of the fifteenth century, ${ }^{111}$ and a similar composition has been presumed to have decorated the Lázói chapel in Gyulafehérvár. ${ }^{112}$

In Székelydálya, this familiar composition was adapted to the context of the sacrament niche: the veil bearing the true Face of Christ was a particularly suitable and popular decoration of the tabernacle containing the Body of Christ in the form of the Eucharist, usually placed directly above the host compart-

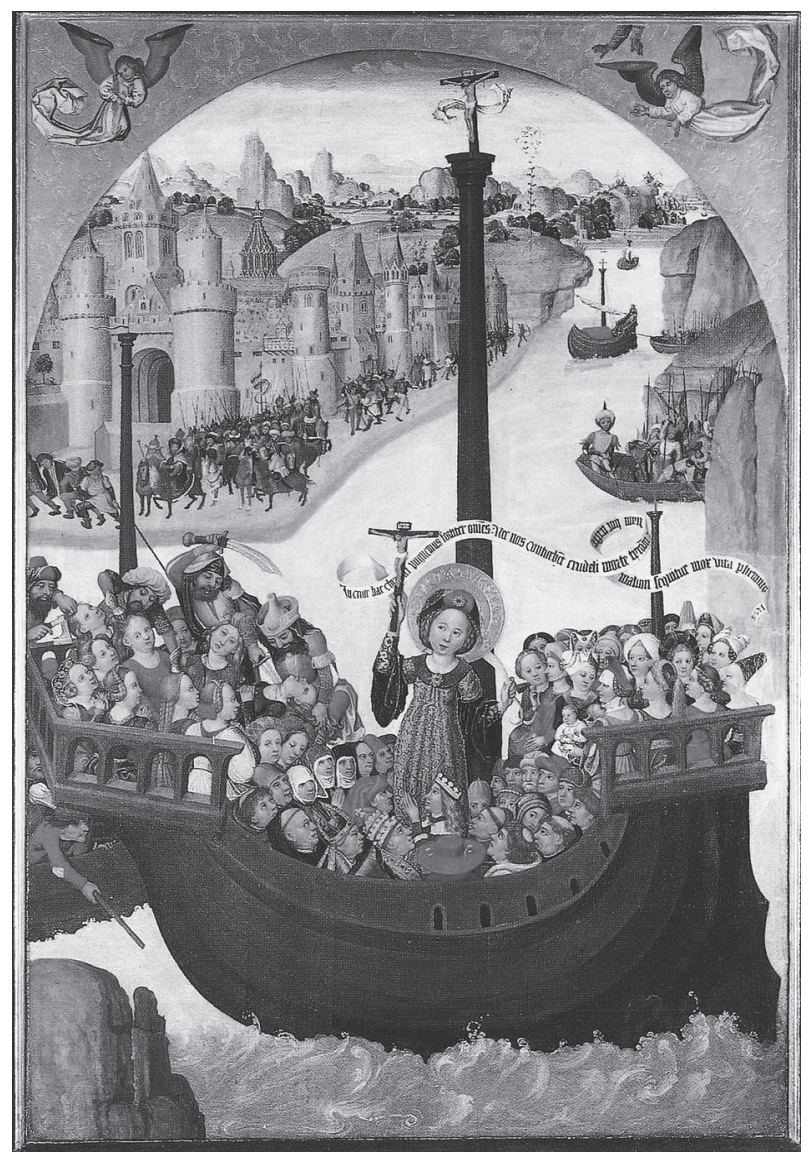

Fig. 29. The martyrdom of Saint Ursula, altarpiece panel; Cistercian nunnery of Lichtental (ZEHNDER, op. cit., Taf. 1)

ment. ${ }^{113}$ The two apostolic saints associated with the Sudarium have become adoring figures who, through their praying gestures, set an example for the viewer in the devotion to the Sacrament.

\section{Segesvár (Sighișoara, Schäßßburg)}

A set of fragmentary representations on the northern sanctuary wall of the Saint Nicholas church in Segesvár may also have served as the decoration of a sacrament niche that was later replaced with the sacrament house visible today. ${ }^{114}$ In the upper register, to the left of the sacrament house there is a partially surviving composition featuring an angel figure with the Arma Christi evoking different moments of Christ's Passion: the cross with the crown of thorns, the ladder, rooster, lance and sponge on a reed (Fig. 31). In the lower register, the mourning figure of Saint John the Evangelist suggests that a three-figure Crucifixion might have originally been painted here, ${ }^{115}$ which was flanked by the figures of Saint Ursula and Saint Barbara (Fig. 32). 
Both standing figures are represented in half profile, turning towards the composition in the centre, from which they are separated by an illusionistic frame. Both of them are wearing crowns, their long hair spreading over their mantle, and holding their traditional attributes: Saint Ursula her arrow, ${ }^{116}$ and Saint Barbara holding a tower in her right hand, while in her left hand fragments of a golden chalice, most likely with the host above it, can be discerned.

Of the two virgin saints, it is Saint Barbara whose cult and iconography is most evidently linked to the devotion to the Sacrament stored in the tabernacle. Her late medieval cult was based on her role as an intercessor in the hour of death, ensuring that her devotees would not die without confession and communion. This task to protect against sudden death by securing the administration of the last sacrament is visualized in her attribute, the chalice with the host, which from the fifteenth century onwards was added to her original attribute, the tower. ${ }^{117}$

Consequently, Saint Barbara was probably the saint whose association with the Eucharist was most emphatic and most frequent in Late Gothic art, ${ }^{118}$ and whose figure was also an obvious choice for the decoration of sacrament houses and niches. ${ }^{119}$ Several authors point out the role of the clergy in the promotion of the cult of Saint Barbara in the context of constructing a eucharistic discourse where clerics act as mediators of divine grace through the sacraments, ${ }^{120}$ which were indispensable not only for a good Christian life, but also to secure a good Christian death. ${ }^{121}$ Thus, representations of Saint Barbara in a sacramental context, besides an expression of the devotion to the saint, may also serve as reminders of the importance of the last communion. ${ }^{122}$

In the upper register of the northern sanctuary wall, in the tympanum of the vaulting in the second bay from the west, the standing figure of Mary Magdalene is visible, holding her ointment jar in her hands (1484; Fig. 33). The donor figure kneeling before her has been hypothetically identified as Michael Polner, ${ }^{123}$ mayor of the town, who had played an important role in the Late Gothic rebuilding of the church. Between the two figures a plant pot can be seen, the whole composition being framed by an unusually long decorative inscription scroll, for the most part unreadable. ${ }^{124}$

In her study of the wall painting, Corina Popa remarks that, just as in the case of the donor portraits on the western side of the triumphal arch, this votive image was associated with representations evoking Christ's sacrifice in the lower register, and suggests

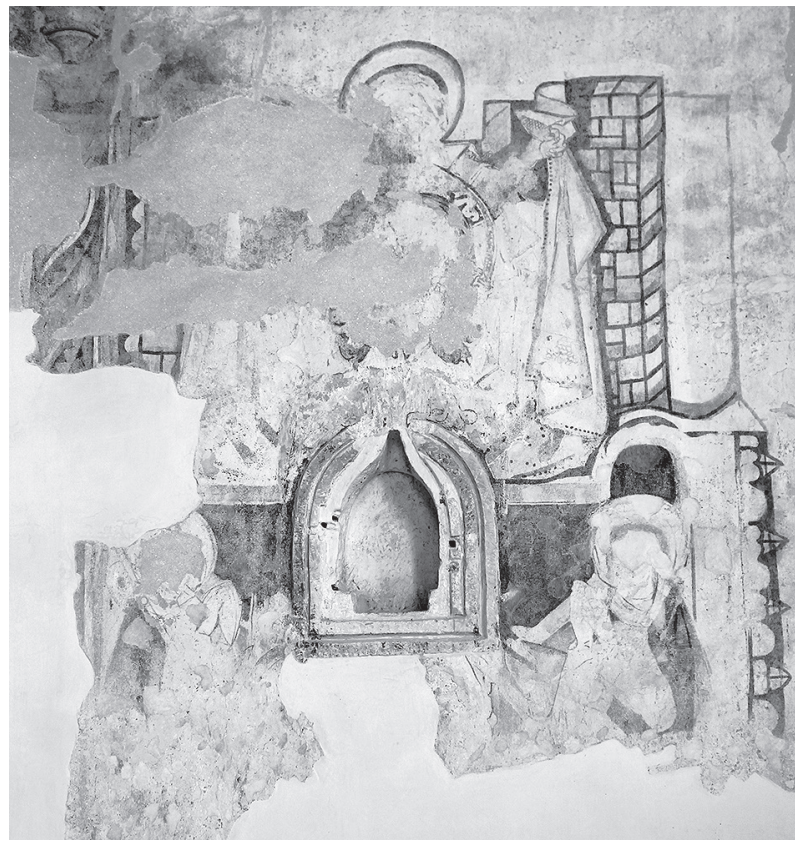

Fig. 30. The veil of Veronica, Saint Peter and Saint Paul; Székelydálya, parish church (photo by the author)

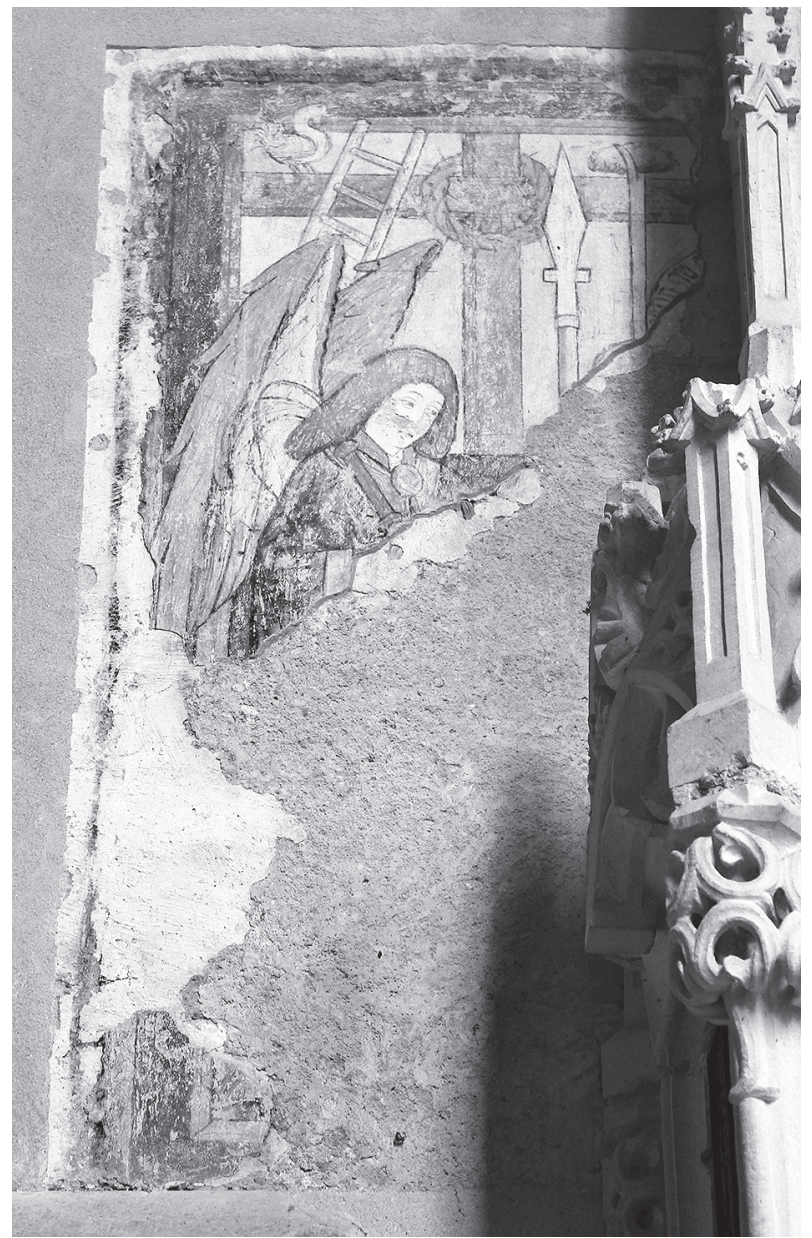

Fig. 31. Angel with the Arma Christi; Segesvár, Saint Nicholas church (photo by the author) 


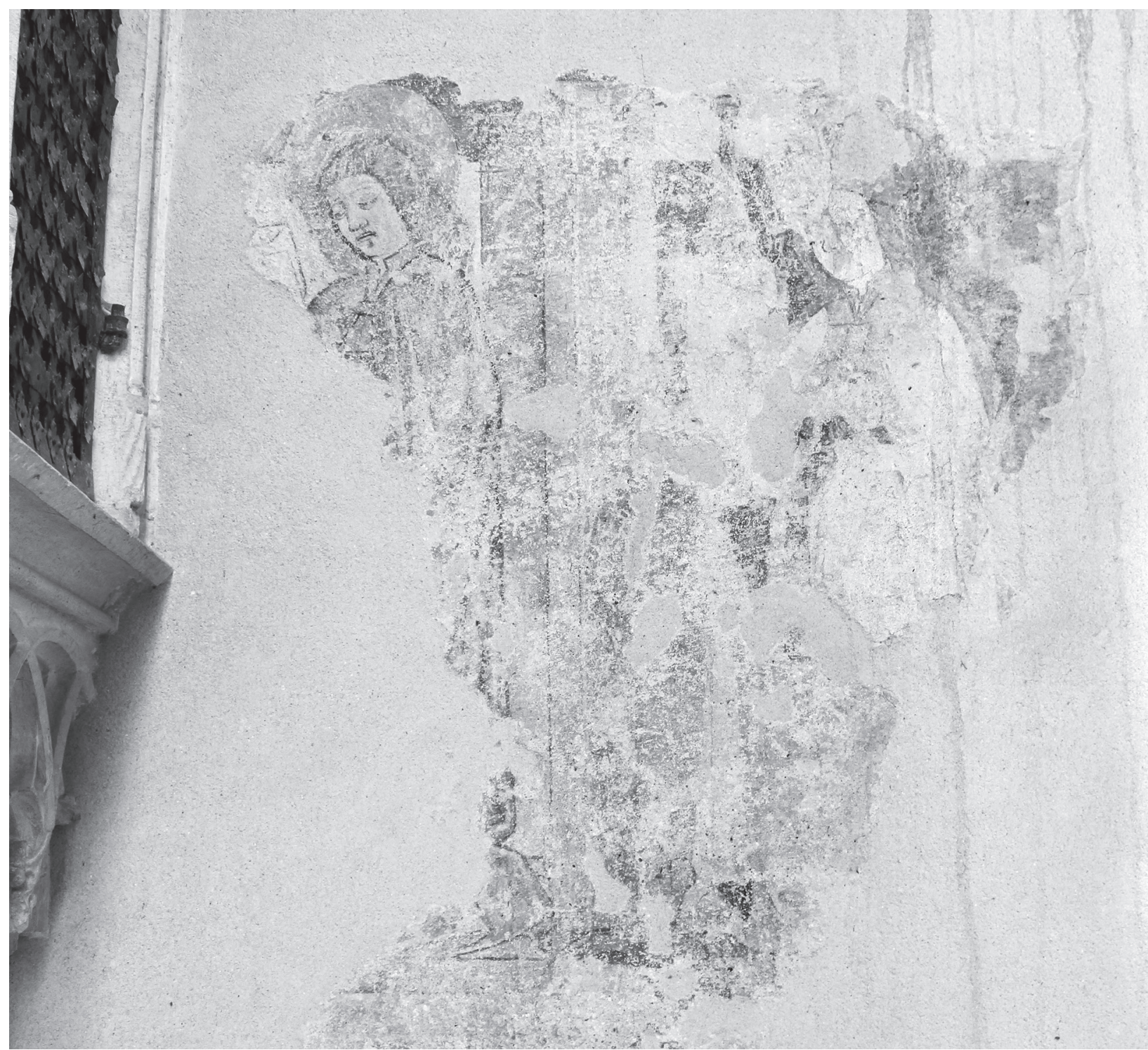

Fig. 32. Saint John the Evangelist, Saint Barbara; Segesvár, Saint Nicholas church (photo by the author)

that the saint's key role played in the Passion story probably earned her this privileged place within the decoration of the chancel. ${ }^{125}$ Indeed, Mary Magdalene plays an important role in the Gospel narratives not only as a witness of Christ's Crucifixion and Entombment, but also as a discoverer of the empty tomb, and, according to some accounts, the first person to encounter the risen Christ. ${ }^{126}$

At the same time, an important aspect of her cult was that as a repenting sinner, she was set as an example of perfect penance for the believers, primarily in mendicant preaching. ${ }^{127}$ The reverence for the saint is also traceable among the Dominicans of the town of Segesvár, who, not long after the completion of the sanctuary decoration of the parish church, commissioned an altarpiece for an altar dedicated to Mary Magdalene. ${ }^{128}$
As Katherine Ludwig Jansen argues in her monograph on the saint, one of the main factors behind the late medieval flourishing of Mary Magdalene's cult was the reformulation of the sacrament of penance at the Fourth Latheran Council in 1215, by making an annual confession of sins obligatory. ${ }^{129}$ The same decree Omnis utriusque sexus also required all believers to take communion at least once a year at Easter, for which confession and penance were a prerequisite, cleansing and preparing the penitent for the reception of the Eucharist. The close connection between the sacraments of confession and communion, characteristic for late medieval religiosity, ${ }^{130}$ can also be observed in the case of the veneration of Mary Magdalene, whose example served not only to promote the cult of penance but also to provide a model for 


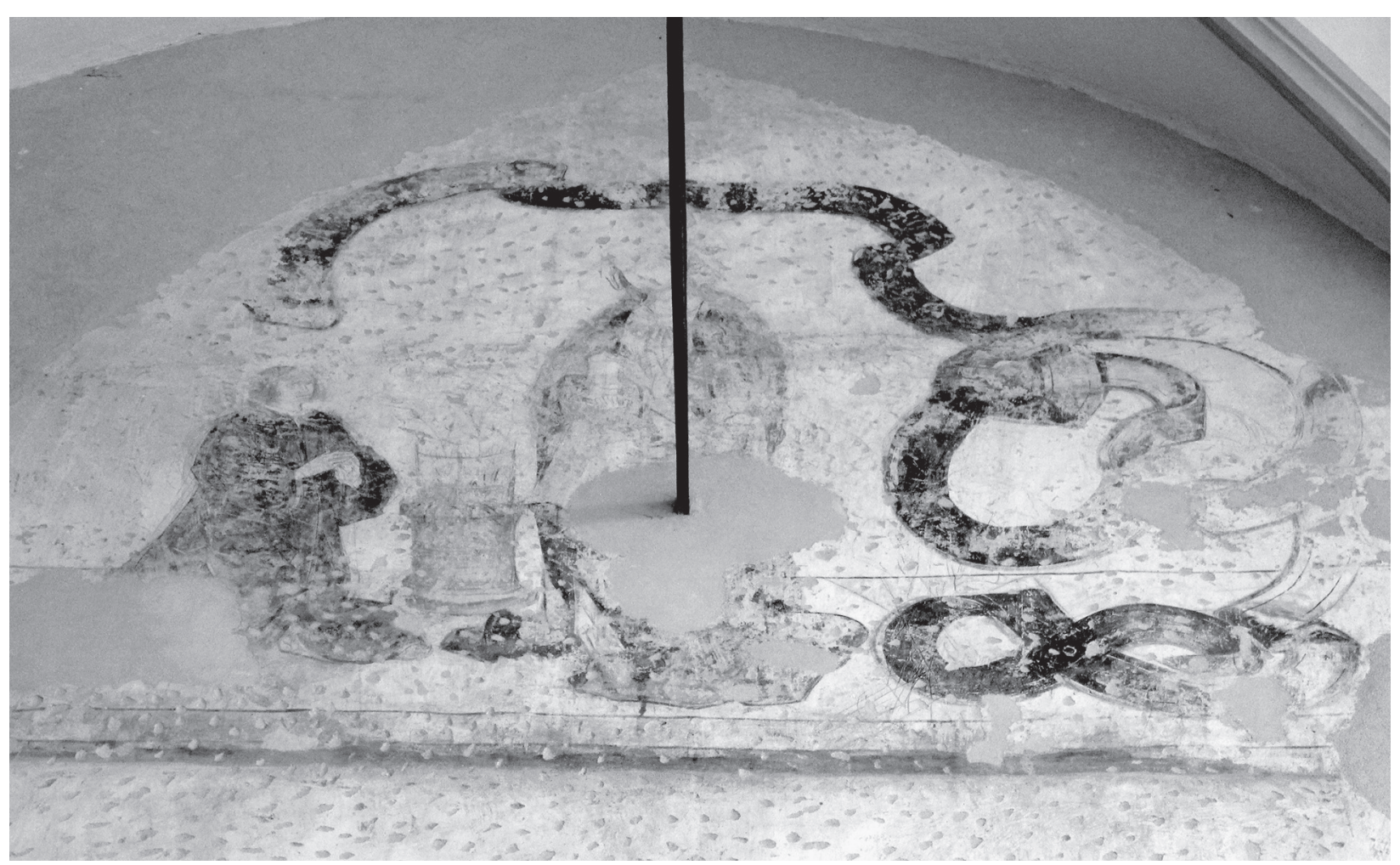

Fig. 33. Mary Magdalene with a donor figure; Segesvár, Saint Nicholas church (photo by the author)

devotion to the Eucharist. ${ }^{131}$ In the last episode of her life as narrated in the Golden Legend, when feeling the approach of her death after thirty years of retirement in the desert, she announces bishop Maximian to meet her in the church, where, accompanied by a choir of angels, shedding tears of joy, [she] received the Lord's Body and Blood from the bishop, before she lay down in front of the altar and her soul departed to God. ${ }^{132}$ The Last Communion of Mary Magdalene was a popular eucharistic theme in mendicant sermons, as well as in wall paintings and altarpieces primarily in Italy, but also north of the Alps. ${ }^{133}$ The figure of Mary Magdalene was also frequently incorporated in the iconographic programs of tabernacles. ${ }^{134}$ On the sacrament house in the Saint James' church in Rothenburg ob der Tauber (Germany) the figures of Saint Barbara with her chalice and Mary Magdalene with her ointment jar are flanking the host compartment. ${ }^{135}$ In the fourteenth-century wall painting decoration of the sacrament niche in Väskinde (Sweden) Mary Magdalene appears kneeling before the figure of the enthroned Christ, wiping his feet with her hair. In an analysis of this rare iconographic composition, Mereth Lindgren interprets the figure of the sinner saint as a personification of the faithful in their devotion to the Corpus Christi stored in the tabernacle. ${ }^{136}$

The reasons behind the donor's choice to be represented in the company of Mary Magdalene in Segesvar remain unclear. Besides her close association with Christ as recorded in the Gospels, a further appeal of the saint as an intercessor and model may have been her hopegiving transformation from a sinner into a saint, suggesting both the importance and efficacy of the sacraments of penance and communion in attaining salvation.

\section{CONCLUSION}

The examples discussed above constitute only a part of the hagiographical representations in the late gothic wall painting decoration of sanctuaries, many of which have no discernible eucharistic connotations. Although in the selection of saints to be represented in the chancel - just as in any part of the church - fac- tors like the spread of a saint's cult and a need for his or her intercession, as well as personal preferences of the donors and the inventors of the iconographic programs must have played a primary role, some representations of saints seem to carry an additional layer of meaning connected to eucharistic devotion. The fact 
that most of the latter images are located in the sanctuary ${ }^{137}$ suggests conscious choices on the part of the inventors of the iconographic programs in adapting the subject matter of the wall paintings to the function of the given liturgical space.

Based on the way they evoke the Eucharist, the representations can be divided into two groups: while some explicitly depict the eucharistic species contained in a monstrance or a chalice, or make a reference to it in the form of heavenly nourishment provided to a saint, others allude to the sacramental body of Christ in a subtler way, by recalling Christ's sacrifice on the cross through specific iconographic details. This parallelism is most explicit in cases when - using Timmermann's typological framework of interpretation - the connection between the saintly martyrdom (the type) and Christ's crucifixion (the antitype) is suggested either by the juxtaposition of the two (Nagyszeben) or their combination within one composition (Székelydálya).

While often the association of a saint with the sacrament can readily be traced back to their cult and legend, in some cases it seems to be more incidental, such as the equipment of Saint Valentine with a monstrance, or the representation of Saint Peter and Saint Paul as adoring figures flanking the tabernacle. Both compositions can be explained with the use of visual sources taken from a different context (here: the veneration of relics), which acquire an additional, eucharistic meaning in the new context.

Due to the fragmentary survival of chancel decorations from this period, it is difficult to draw a general conclusion about the place of hagiographical compositions with eucharistic connotations in the iconographic programs. In cases when they can be analysed in the context of other elements of the contemporary chancel decoration, representations of saints bearing eucharistic connotation tend to supplement more conventional, straightforward eucharistic imagery - such as the Crucifixion, Arma Christi or Veronica's Veil which provide a reference point for the interpretation of the images of saints set in the service of eucharistic devotion.

\section{NOTES}

${ }^{1}$ This research was supported by a grant of the Romanian National Authority for Scientific Research and Innovation, CNCS - UEFISCDI, project number PN-II-RUTE-2014-4-2293.

2 See for instance PaLAzzo, Eric: Art and Liturgy in the Middle Ages: Survey of Research (1980-2003) and Some Reflections on Method, The Journal of English and Germanic Philology 105. 2006. 175-178; SteENSMA, Regnerus: Anordnungsprinzipien der Wandmalereien in Groninger Kirchen, in Wandmalerei in Niedersachsen, Bremen und im Groningerland: Fenster in die Vergangenheit, eds. GROTE, Rolf-Jürgen - VAN DER PLOEG, Kees, Hannover: Deutscher Kunstverlag, 2001. 99-100.

${ }^{3}$ For a summary of this development and further bibliography, see VAN AUSDALL, Kristen: Art and Eucharist in the Late Middle Ages, in A Companion to the Eucharist in the Middle Ages, eds. LEvy, Ian Christopher - MACY, Gary - VAN AusDALl, Kristen, Leiden-Boston: Brill, 2012. 541-618.

${ }^{4}$ Vloberg, Maurice: L'eucharistie dans l'art, Grenoble: B. Arthaud, 1946. 255-269.

${ }^{5}$ DAMBECK, Franz: Eucharistische Heiligenattribute, in Eucharistia: deutsche eucharistische Kunst. Offizielle Ausstellung zum Eucharistischen Weltkongress, ed. RiTz, Gislind M., München: Schnell und Steiner, 1960. 25-28.

${ }^{6}$ Timmermann, Achim: Real Presence: Sacrament Houses and the Body of Christ, c. 1270-1600, Turnhout: Brepols, 2009. 303-307.

${ }^{7}$ DitTMEYer, Daria: Gewalt und Heil: Bildliche Inszenierungen von Passion und Martyrium im späten Mittelalter, Köln: Böhlau, 2014. 142-145.

${ }^{8}$ LÁNGi, József - MiHÁly, Ferenc: Erdélyi falképek és festett faberendezések I-III [Transylvanian Wall Paintings and
Painted Furniture], Budapest: Állami Múemlékhelyreállítási és Restaurálási Központ, 2002-2006. II. 8-9.

${ }^{9}$ GeRMAn, Kinga: Sakramentsnischen und Sakramentshäuser in Siebenbürgen, Petersberg: Michael Imhof Verlag, 2014 174; JENEI, Dana: Thèmes iconographiques et images dévotionelles dans la peinture murale médiévale tardive de Transylvanie (deuxième parti du XV siècle - premier quart du $\mathrm{XVI}^{\mathrm{e}}$ siècle), Revue Roumaine d'Histoire de l'Art. Série BeauxArts 51. 2014. 31-32.

10 Jerome: The Life of Paulus the First Hermit (hereafter The Life of Paulus), in Nicene and Post-Nicene Fathers. Second series. I-XIV., trans. Fremantle, W. H., Edinburgh: T\&T Clark, 1892. VI. 699; Saint Paul is represented in a robe woven of palm leaves for instance in the altarpiece of Saint Anthony from Szepesszombat (Spišská Sobota, Slovakia), c. 1503-1505, or in the Isenheim altarpiece by Matthias Grünewald (1512-1516).

${ }^{11}$ Lexikon der christlichen Ikonographie I-VIII. (hereafter LCI), ed. KIRSCHBAUM, Engelbert, Rom-Freiburg-BaselWien: Herder, 1968-1976. V. 207-210.

12 While in some representations of the meeting of the two saints his robe made of palm leaves differentiates Saint Paul from Saint Anthony, the two saints are often wearing the same monastic habit and cannot be differentiated from each other by their appearance (for instance in the wall painting cycle in Szepesdaróc (Dravce, Slovakia). In a wall painting decorating the triumphal arch in Mártonhely (Martjanci, Slovenia), Saint Paul the Hermit is wearing a grey monastic vestment and is holding an open book in his hands, similarly to the representation in Alsóbajom. 
13 The Life of Paulus, 699; De Voragine, Jacobus: The Golden Legend (hereafter The Golden Legend), trans. GRANGER RYAN, William, Princeton: Princeton University Press, 2012. 85.

${ }^{14}$ In the altarpiece in Szászbogács (Băgaciu, Bogeschdorf) and possibly that from Nagydisznód (Cisnădie, Heltau), as well as in the wall paintings in Székelyderzs (Dârjiu) and Alcina (Alțâna, Alzen), see FIREA, Ciprian: Arta polipticelor medievale din Transilvania (1450-1550) I-II. [The Art of Transylvanian Winged Altarpieces (1450-1550)] Ph.D. dissertation, Cluj-Napoca, Babeș-Bolyai University, 2010. II. 33, 111-113 and KóNYA, Anna: Ikonográfiai összefüggések az alcinai templom falképein [Iconographic Interconnections in the Wall Paintings of the Parish Church in Alcina], in Kóstolni a szép-tudományba - Tanulmányok a Fiatal Múvészettörténészek IV. Konferenciájának elôadásaiból [Proceedings of the $4^{\text {th }}$ Conference of Young Art Historians], ed. SzÉKelY, Miklós, Budapest: Centrart Egyesület, 2014. 54.

${ }^{15}$ The saint may have appeared in the altarpiece of Saint John the Baptist from Nagydisznód based on a description from 1879, see FIREA, op. cit., II. 111-113. A hermit saint in the altarpiece from Brulya (Bruiu, Braller) described previously as Saint Paul the Hermit has been reidentified as Saint Onuphrius by Emese Sarkadi Nagy (SARKADI NAGY, Emese: Local Workshops - Foreign Connections. Late Medieval Altarpieces from Transylvania, Ostfildern: Thorbecke Verlag, 2012. 155). At the same time, the saint is represented in an altarpiece panel of the meeting of Saint Paul and Saint Anthony from Százhalom (Movile, Hundertbücheln), c. 1520, FIREA, op. cit., II. 245-248.

${ }^{16}$ KNAPP, Éva: Remete Szent Pál csodái [The Miracles of Saint Paul the Hermit], in "Mert ezt Isten hagyta...": Tanulmányok a népi vallásosság köréból ["For God Let This Happen": Studies on Popular Religion], ed. TüskÉs, Gábor, Budapest: Magvetó, 1986. 118-122, 155.

${ }_{17}$ Dicționarul mănăstirilor din Transilvania, Banat, Crișana şi Maramureş [Dictionary of the Monasteries in Transylvania, Banat, Crișana and Maramureș], ed. Rusu, Adrian Andrei, Cluj-Napoca: Presa Universitară, 2000. 203-204.

${ }_{18}$ The Life of Paulus, 699; The Golden Legend, 85.

${ }^{19}$ The Golden Legend, 85.

${ }^{20}$ Historisches Museum der Stadt Budapest, ed. BuzinKay, Géza, Budapest: Corvina, 1995. 55, 146, Fig. 57. On the dating and possible sites of origin of the keystone see also LóVEI, Pál: Néhány címeres emlék a 14-15. századból [Heraldic Monuments from the 14-15 $5^{\text {th }}$ Centuries], Múvészettörténeti Értesítô 40. 1991. 53-55.

${ }^{21}$ Lyster, William: The Cave Church of Paul the Hermit at the Monastery of St. Paul, Egypt, New Haven: Yale University Press, 2008. 37.

22 SAXON, Elizabeth: Carolingian, Ottonian and Romanesque Art and the Eucharist, in A Companion to the Eucharist in the Middle Ages, eds. LEVy, Ian Christopher - MACY, Gary - Van Ausdall, Kristen, Leiden-Boston: Brill, 2012. 294.

${ }^{23}$ The Life of Paulus, 699. On the interpretation of this episode, see: Ó CARRAGáin, Éamonn: The Meeting of St. Paul and St. Anthony: Visual and Literary Uses of a Eucharistic Motif, in Keimelia: Studies in Archaeology and History in Honour of Tom Delaney, eds. MacNiocaill, Gearóid - Wallace, Patrick, Galway: Galway University Press, 1988. 37-45 and WeHLI, Tünde: Remete Szent Antal útja Pálhoz [The Journey of Saint Anthony the Great to Paul], in Decus solitudinis: pálos évszázadok [Pauline Centuries], eds. SARBAK, Gábor - ÔZE, Sándor, Budapest: Szent István Társulat, 2007. 569-571.

24 Ó Carragáin, op. cit., 3-19.

${ }^{25}$ Halfen, Roland: Chartres: Schöpfungsbau und Ideenwelt im Herzen Europas. Architektur und Glasmalerei, Stuttgart: Mayer, 2006. 499-500.

${ }^{26}$ FleischHAUeR, Werner: Zur Herkunft des Basler Eremitenbildes von 1445, Jahrbuch der Staatlichen Kunstsammlungen in Baden-Württemberg 25. 1988. 48-53.

${ }^{27}$ N. Tóth, Ágnes: Hozzászólások a Tízezer vértanú ikonográfiájához. Egy püspök a mártírok körében [On the Iconography of the Ten Thousand Martyrs. A Bishop among the Martyrs], in Omnis creatura significans: tanulmányok Prokopp Mária 70. születésnapjára [Essays in Honour of Mária Prokopp], eds. Kerny, Terézia - Tüskés, Anna, Budapest: CentrArt Egyesület, 2009. 140. See also StÖCKER, Christoph: Dürer, Celtis und der falsche Bischof Achatius. Zur Ikonographie von Dürers 'Marter der Zehntausend,' Artibus et Historiae 5/9. 1984. 121-137.

${ }^{28}$ De x millibus crucifixis mm, in Acta Sanctorum Junii. Tomus IV. (Antwerp, 1707), 182-188, see also N. TótH, op. cit., 141-142 for a Hungarian summary of the chapters of the legend.

${ }^{29}$ Acta SS. Junii, op. cit., 186

${ }^{30}$ Beati erimus, si digni fuerimus expiari talibus tormentis, quia merebimur communicare passionibus Christi (Ibid., 185); Gloria tibi Christe: quia essemus indigni, dignos nos fecisti suscipere passiones tuas (Ibid., 186).

${ }^{31}$ On visual references to Christ's Passion in representations of the Martyrdom of the Ten Thousand see also N. Tóth, op. cit., 138-140 and SARKADI NAGY, op. cit., 75-78.

32 LCI V. 19.

${ }^{33}$ See SARKAdI NAgY, op. cit., 78 for examples of this compositional type.

${ }^{34}$ On the identification of the bishop saint as Hermolaus instead of Achatius, see STÖCKER, op. cit., 125-127. On the wall painting in Medgyes see DrĂGUȚ, Vasile: Picturile murale de la Mediaș: o importantă recuperare pentru istoria artei transilvănene [The Mural Paintings from Mediaș: An Important Recovery for the History of Transylvanian Art], Revista muzeelor și monumentelor - Seria Monumente istorice și de artă 14. 1976. 17-18.

${ }^{35}$ N. Tóth, op. cit., 138-139; Dittmeyer, op. cit., 135; ZeHnder, Frank Günter: Katalog der Altkölner Malerei. Kataloge des Wallraf-Richartz-Museums, XI. Köln: Wienand, 1990. 105-107, Abb. 75.

36 Such as the Christ-like physiognomy of one of the martyrs wearing a crown of thorns, waiting to be crucified between two other martyrs positioned as the good and the bad thief flanking a central (not yet erect) cross. See PANOFSKY, Erwin: Albrecht Dürer, I-II. Princeton, New Jersey: Princeton University Press, 1948. I. 121.

${ }^{37}$ Ibid., I. 121-122.

38 SUCKALE, Robert: Ein Tüchleinbild der Achatiusmarter aus der Nachfolge des Meisters von St. Lambrecht, GalériaRočenka Slovenskej národnej galérie v Bratislave 2001. 80-81; N. Tóth, op. cit., 139-140; SARKADI NAGY, op. cit., 76-78.

${ }^{39}$ For instance a tempera panel from Rokitó (Rokytov), c. 1450 (N. Tо́тн, op. cit., 137-141), the altarpiece of Mary Magdalene in Berki (Rokycany), c. 1480-1490, the altarpiece of Saint Margaret in Malompatak (Mlynica) c. 1515- 
1520, or the altarpiece of the Church Fathers from Kisszeben (Sabinov) c. 1510-1520. RadoCsay, Dénes: A középkori Magyarország táblaképei [The Panel Paintings of Medieval Hungary], Budapest: Akadémiai Kiadó, 1955. 279, 358, 386-387.

40 See SARKADI NAGY, op. cit., 75-78.

${ }^{41}$ DitTMeyer, op. cit., 145; N. Tóth, op. cit., 140

${ }^{42}$ Malarstwo gotyckie $w$ Polsce I-III. [Gothic Painting in Poland], eds. LabUdA, Adam. S. - SeComSKA, Krystyna, Warszawa: Instytut Sztuki PAN, 2004. II. 63, III. Fig. 40.

43 SuCKale, op. cit., 80, Fig. 7.

${ }^{44}$ The wall paintings of the southern sanctuary wall were revealed during a renovation of the church in the summer of 2016, by a group of restorers led by Lóránd Kiss. On the history and architecture of the church see: SALONTAI, Mihaela Sanda: Mănăstiri dominicane din Transilvania [Dominican Monasteries from Transylvania], Cluj-Napoca: Nereamia Napocae, 2002. 224-227.

${ }^{45}$ LCI V. 19-20. On the joint representation of the two martyrdom scenes see also TüskÉs, Anna: The Cult of St Ursula in Hungary: Legend, Altars and Reliquaries, in The Cult of Saint Ursula and the 11,000 Virgins, ed. CARTwright, Jane, Cardiff: University of Wales Press, 2016. 196, and RicHES, Samantha: Male Martyrs, Female Models? St Ursula and St Acacius as Leaders and Victims, in ibid., 251-252.

${ }^{46}$ Timmermann, op. cit., 304. The term is used similarly for hagiographical counterparts of Old Testament prefigurations of the life of Christ in MonHAUPT, Bernd: Typologisch strukturierte Heiligenzyklen: Die Adalbertsvita der Gnesener Bronzetür, in Hagiographie und Kunst. Der Heiligenkult in Schrift, Bild und Architektur, ed. KerSCHER, Gottfried, Berlin: Dietrich Reimer, 1993. 357-368.

${ }^{47}$ Although in the case of Saint Valentine the cult and iconography of several saints of the same name have merged, none of them contains references to the Eucharist. LCI VIII. 529-531. On Valentine as a patron of the epileptics see: TemkIn, Owsei: The Falling Sickness: A History of Epilepsy from the Greeks to the Beginnings of Modern Neurology, Baltimore: Johns Hopkins University Press, 2010. 101, and JARITZ, Gerhard: Signs of Mental Disorder in Late Medieval Visual Evidence, in Mental (Dis)Order in Later Medieval Europe, eds. Katajala-PeltomaA, Sari - Nitranen, Susanna, Leiden-Boston: Brill, 2014. 93-97.

${ }^{48}$ Recent literature on the altarpiece housed in the Lutheran church of Nagydisznód with references to earlier scholarship: SARKADI NAGY, op. cit., 153-155; FIREA, op. cit., II. 77-83.

${ }_{49}$ As the composition of the mural is more crowded, with less space between the standing figures than in the altarpiece panel, only the upper body of the epileptic fitted in, but the posture and clothing of the two lying figures are similar.

${ }^{50}$ The monstrance is rendered differently in the altarpiece panel, having a more embellished and sophisticated design, adorned with a spire and pinnacles.

${ }^{51}$ On the Wittenberger Heiltumsbuch see CÁRDENAS, Livia: Friedrich der Weise und das Wittenberger Heiltumsbuch: mediale Repräsentation zwischen Mittelalter und Neuzeit, Berlin: Lukas Verlag, 2002.

52 Although the reliquary of Saint Valentine does not survive, there is another, more faithful, copy of it almost contemporary with the woodcut, which gives a more accurate picture of how the reliquary might have looked like (reproduced in CÁRDENAS, Livia: Kollektionskataloge des Heiligen:
Reliquiensammlungen im Bild, in Collectors' Knowledge: What is Kept, What is Discarded, eds. Goeing, Anja-Silvia Grafton, Anthony T. - Michel, Paul, Leiden-Boston: Brill, 2013. 184, Fig. 14). See here also for an analysis of how Cranach had transposed the reliquary statues into the medium of prints when illustrating the Heiltumsbuch: ibid., 178-183.

53 Another link between the altarpiece and the wall painting is the rare representation of an unidentified bishop saint with a dog as an attribute, paired with Saint Valentine in the altarpiece panel and represented as the fourth standing bishop saint in the mural.

${ }^{54}$ About the wall painting see DARKÓ, László: A kolozsvári Szent Mihály-templom 1956/57. évi helyreállítása során feltárt falfestmények [The Wall Paintings Revealed during the Renovation of the Saint Michael's Church in Kolozsvár in 1956/1957], in Emlékkönyv Kelemen Lajos születésének nyolcvanadik évfordulójára [Festschrift for the $80^{\text {th }}$ Birthday of Lajos Kelemen], eds. BODOR, András et al., Bukarest: Tudományos Könyvkiadó, 1957. 207-210, 217; LÁNGI-MIHÁLY, op. cit., III. 78.

${ }^{55}$ Mihály Jánó (in a presentation given at the conference Mũemlékvédelem Erdélyben IV. [Heritage Protection in Transylvania IV.], Szováta, March 2010, with the title Megjegyzések a kolozsvári Szent Mihály-templom falképeinek ikonográfiájához [Remarks on the Iconography of the Wall Paintings in the Saint Michael's Church in Kolozsvár]) and Dana Jenei (JeNEI, op. cit., 27) also identify the saint as Fabian.

${ }^{56}$ LCI VI. 215. There are also numerous examples of their common veneration in Transylvania. Written sources mention chapels dedicated to Saint Sebastian and Saint Fabian in Sólyomkő (Șoimeni, 1485) and in the Dominican convent of Kolozsvár (1531), altars dedicated to the two saints in the cathedral of Gyulafehérvár (Alba Iulia), and the parish church of Nagyszeben, and a donation of a stone column in the honour of Saint Sebastian and Saint Fabian with the image of the saints painted on it to the church of the Virgin Mary in Magyarzsombor (Zimbor, 1482). Saints Sebastian and Fabian were also depicted as a pair in the altarpiece from Brulya. See A kolozsmonostori konvent jegyzôkönyvei (1289-1556) I-II. [The Records of Kolozsmonostor Convent (1289-1556)], ed. JaKó, Zsigmond, I., 799-800, no. 2342, II. 17, no. 2516; Oklevéltár Kolozsvár története elsô kötetéhez [Cartulary to the First Volume of the History of Kolozsvár], ed. JakAB, Elek, Buda: Egyetemi Nyomda, 1870. 374; FIREA, op. cit., II. 78, 221.

${ }^{57}$ Marshall, Louise: Manipulating the Sacred: Image and Plague in Renaissance Italy, Renaissance Quarterly 47/3. 1994. 489, 493. On the cult of Sebastian as a plague saint see also Ressouni-Demigneux, Karim: La personnalité de saint Sébastien: Exploration du fonds euchologique médiéval et renaissant, du IVe au XVIe siècle, Mélanges de l'Ecole française de Rome: Moyen Age 114. 2002. 557-579.

${ }^{58}$ Mazza, Enrico: The Celebration of the Eucharist: The Origin of the Rite and the Development of Its Interpretation, Collegeville: Liturgical Press, 1999. 134-137.

${ }^{59}$ The Golden Legend, 100; Marshall, op. cit., 495.

${ }^{60}$ Ibid., 495-496.

${ }^{61}$ LCI VIII. 318.

62 Examples: Master MM, The Lamentation (1515), Springfield Museums, Springfield, see Hope and Healing: Painting in Italy in a Time of Plague, 1500-1800, eds. Bailey, 
Gauvin Alexander et al., Worcester: Worcester Art Museum, 2005. 163, Fig. 67; Altarpiece of the Suffering Trinity, c. 1500 , Stadtmuseum Simeonstift Trier, (for a reproduction see Bildarchiv Foto Marburg, image no. 59.172, http:// www.bildindex.de/document/obj20746717?part=0\&medi um=mi03103e10, last accessed June 2017). In the Resurrection triptych by Hans Memling the martyrdom of Saint Sebastian represented on the left wing seems to stand out from among the Christological scenes of the Resurrection in the center and the Ascension on the right wing. However, Barbara Lane argues that the martyrdom scene can be seen as substituting a composition representing the sacrifice of Christ, which could have been expected to precede the Resurrection. LANE, Barbara: Hans Memling: Master Painter in Fifteenth-Century Bruges, London-Turnhout, Belgium: Brepols, 2009. 306

${ }^{63}$ On the Saint Sebastian chapels in Venanson, St. Etienne de Tinnée and Roubion (France) see Beauchamp, Philippe de: L'art religieux dans les Alpes-Maritimes: architecture religieuse, peintures murales et retables, Aix-en-Provence: Édisud, 1990. 65-66, 77-79, 84-86.

${ }^{64}$ Weingartner, Josef: Die Kunstdenkmäler Südtirols, I-II. Bozen-Innsbruck-Wien: Athesia-Tyrolia, 1973. II. 265.

${ }^{65}$ For a discussion of Saint John the Evangelist's chalice as a possible eucharistic symbol see: VLOBERG, op. cit., 255.

${ }^{66}$ Der Meister von Schöder: zur Erhaltung und Erforschung mittelalterlicher Wandmalerei im Ostalpenraum, ed. GOBIET, Ronald, Bad Gastein: ARGE, 2002. 39, Farbtaf. X.

${ }^{67}$ The position of his arms tied to the tree - the left one raised above his head, the right twisted behind his back can be found for example on the Flagellation by the Master of the Calvary (c. 1440-1450). The graceful move of his legs was probably inspired by the large Sebastian of Schongauer (Bartsch 59), or even more probably a reverse copy by Wenzel von Olmütz. The position of the arrows too largely corresponds to that on this print, which, in turn, also bears close resemblance to compositions of the Flagellation of Christ.

${ }^{68}$ DORMEIER, Heinrich: Laienfrömmigkeit in den Pestzeiten des 15./16. Jahrhunderts, in Maladies et société (XIIe-XVIIIe siècles): Actes du colloque de Biefeld, novembre 1986, eds. Bulst, Neithard - DELORT, Robert, Paris: Editions du CNRS, 1989. 288. On the problem of who can be regarded as a "plague saint" see ibid. 284-298 and idem, Saints as Protectors against Plague: Problems of Definition and Economic and Social Implications, in Living with The Black Death, eds. BISGAARD, Lars - SøNDERGAARD, Leif, Odense: University Press of Southern Denmark, 2009. 169-170.

${ }^{69}$ Ibid., 167.

${ }^{70}$ LCI VIII. 530. The representation of Saints Sebastian, Fabian and Roch as a trio appears as a wall painting, for instance, in the Holy Trinity Church in Hrastovlje, Slovenia (c. 1490), the parish church of Benna, Italy (1515-1520) or the Saint George's church in Albenga, Italy (1476).

${ }^{71}$ LCI VI. 215.

72 Decrees of Fabian, in Ante-Nicene Christian Library. Translations of the Writings of the Fathers down to A.D. 325. IX. The Writing of Hippolytus, Bishop of Portus. Fragments of Third Century, eds. RoBERTs, Alexander - DONALDSON, James, Edinburgh: T. \& T. Clark, 1869. 272-274.

${ }^{73}$ IzBICKI, Thomas M.: The Eucharist in Medieval Canon Law, Cambridge: Cambridge University Press, 2015. 87, 140,142
${ }^{74}$ Boeckl, Christine M.: Images of Plague and Pestilence: Iconography and Iconology, Kirksville, Mont: Truman State University Press, 2000. 43, 88, 90, 110; DORMEIER, Heinrich: "Ein geystliche ertzeney fur die grausam erschrecklich pestilentz". Schutzpatrone und frommer Abwehrzauber gegen die Pest, in Das große Sterben. Seuchen machen Geschichte. Ausstellungskatalog (Dresden, Deutsches HygieneMuseum), eds. WilderotTer, Hans - DorRmann, Michael, Berlin: Jovis, 1995. 55-57.

${ }^{75}$ ESSER, Thilo: Die Pest-Strafe Gottes oder Naturphänomen? Eine frömmigkeitsgeschichtliche Untersuchung zu Pesttraktaten, Zeitschrift für Kirchengeschichte 108. 1997. 42-45.

${ }^{76}$ The Black Death, ed. Horrox, Rosemary, Manchester: Manchester University Press, 1994. 149.

77 BOECKL, op. cit., 86. Although a physical healing power was attributed to the Eucharist throughout the medieval period (Rubin, Miri: Corpus Christi: The Eucharist in Late Medieval Culture, Cambridge: Cambridge University Press, 1991. 339-342), the sacrament being seen as medicine not only in an allegorical sense, but for actual maladies, there are no miraculous healings of plague victims known (WitTMERButsCh, Maria - Rendtel, Constanze: Miracula. Wunderheilungen im Mittelalter, Köln: Böhlau, 2003. 110)

${ }_{78}$ On the iconography of this panel housed in the Akademie der bildenden Kunst in Vienna, see MarSHaLl, Louise: Plague in the city, identifying the subject of Giovanni di Paolo's Vienna Miracle of Saint Nicholas of Tolentino, Renaissance Studies 27/5. 2013. 654-680.

${ }^{79}$ Regimen zu deutsch Magistri Philippi Culmachers von Eger wider die grausamen erschrecklichenn Totlichen Pestelentz, Leipzig, 1495, see WiLderotTer-Dorrmann, op. cit., 122, and SudHOFF, Karl: Deutsche medizinische Inkunabeln, bibliographisch-literarische Untersuchungen, Leipzig: J. A Barth, 1908. 176-178 (https://archive.org/details/deutschemedizini00sudhuoft, last accessed June 2017).

${ }^{80}$ For an analysis of this print see ESSER, op. cit., 45.

${ }^{81}$ BROWE, Peter: Die Eucharistie im Mittelalter: Liturgiehistorische Forschungen in kulturwissenschaftlicher Absicht, Berlin LIT, 2011. 291.

82 On folios $71 \mathrm{v}$ and $72 \mathrm{r}$.

${ }^{83}$ BOECKL, op. cit., 52

84 The Golden Legend, 101.

85 Ibid., 174. The passage has an Old Testament prototype. In a story related in the Books of Chronicles, God had sent an angel of pestilence upon Israel, who appeared to King David as standing between the earth and the heaven, having a drawn sword in his hand stretched out over Jerusalem. As king David has made offerings at an altar to appease God, the Lord commanded the angel; and he put up his sword again into the sheath thereof (1 Chron 21:14-27). See also: LitTle, Lester K.: Life and Afterlife of the First Plague Pandemic, in Plague and the End of Antiquity. The Pandemic of 541-750, ed. idem, Cambridge: Cambridge University Press, 2007. 31-32.

${ }^{86}$ For example, on the title page of a plague treatise by Philipp Culmacher von Eger (discussed above, see footnote 77). In a Concordantia caritatis manuscript by Ulrich of Lilienfeld (c. 1351-1358) the plague angel sheathing its sword is represented as an Old Testament type for Peter cutting the ear of Malchus (Lilienfeld, Austria), Stiftsbibliothek, cod. 151; fol. 81v (Bilddatenbank REALonline, Institut für Realienkunde des Mittelalters und der frühen Neuzeit, 
Universität Salzburg. image no. 003963, http://tethys.imareal.sbg.ac.at/realonline/, last accessed June 2017). See also: BOECKL, op. cit., 52.

87 SzABÓ, István: Hanyatló jobbágyság a középkor végén [Declining Serfdom at the End of the Middle Ages], Századok 72. 1938. 36-37. See Magyary-KossA, Gyula: Magyar orvosi emlékek. Értekezések a magyar orvostörténet köréból. III. kötet: Adattár 1000-1700-ig [Hungarian Medical Records. Studies on Hungarian Medical History. Vol. III: Repertory 10001700], Budapest: Magyar Orvosi Könyvkiadó Társulat, 1931 for written sources on the individual plague outbreaks.

88 József Huszka: Székelydálya. Az északi fal harmadik mezôje [Székelydálya. The Third Field of the Northern Wall], watercolour copy, 1903, Budapest, Plan Collection of the Hungarian Monument Protection, inv. no. FM 108.

${ }^{89}$ The last three figures are very fragmentarily preserved. On the watercolour copy, the fourth figure seems to be haloed, the fifth is wearing a pointed red hat.

90 HuszKA, József: Magyar szentek a Székelyföldön a XV. és XVI-dik századokban [Hungarian Saints in the Szeklerland in the $15^{\text {th }}$ and $16^{\text {th }}$ Centuries], Archaeologiai Értesitô 6. 1886. 128-130.

${ }^{91}$ TüskÉs, Anna: Szent Orsolya tisztelete a középkori Magyarországon: legendák, ereklyék, oltárok [The Cult of Saint Ursula in Medieval Hungary: Legends, Relics, Altarpieces], Opus Mixtum 3. 2014. 37.

92 BALOGH, Jolán: Az Erdélyi Renaissance [The Transylvanian Renaissance], Kolozsvár: Erdélyi Tudományos Intézet, 1943. 295; LángI-MiHÁLy, op. cit., I. 104-105 (hypothetical identifications).

${ }^{93}$ GomBosi, Beatrix: "Köpönyegem pedig az én irgalmasságom ...”: köpönyeges Mária ábrázolások a középkori Magyarországon = "Mein weiter Mantel ist meine Barmherzigkeit...": Schutzmantelmadonnen aus dem mittelalterlichen Ungarn, Szeged: Néprajzi és Kulturális Antropológiai Tanszék, 2008. 163; GERMAN, op. cit., 256; JenEI, op. cit., 30; SzABÓ, Tekla: Magyarvista középkori templomának donátorképei [The Donor Portraits of the Medieval Church of Magyarvista], Korunk 26/1. 2015. 6.

${ }^{94}$ Examples: Martyrdom of Saint Ursula, altarpiece panel, possibly of Transylvanian origin, c. 1480, private collection: SARKADI NAGY, op. cit., 217-218, Fig II. 148; Martyrdom of Saint Ursula, altarpiece from Homoródbene (Beia, Meeburg), housed in the "Church on the Hill" in Segesvár (Sighișoara, Schäßburg), ibid., 231-234, Fig. II. 167. See TüsKÉS, op. cit., 2014, 39 for further examples.

${ }^{95}$ For instance, in a fresco on the triumphal arch of the Saint Nicholas church in Mače, Slovenia (1467), where in a somewhat similar arrangement as in Székelydálya, the armed Hun soldiers, some of them clad in armour, are emerging through the city gate positioned in the upper right part of the composition to attack the ship (REALonline, image no. 010654, http://tethys.imareal.sbg.ac.at/realonline/, last accessed June 2017).

${ }^{96}$ For example in a miniature in the Très Riches Heures $d u$ Duc de Berry, fol. 178v.

${ }^{97}$ For a summary of the different versions of the legend see ZEHNDER, Frank Günter: Sankt Ursula: Legende, Verehrung, Bilderwelt, Köln: Wienand Verlag, 1987. 13-41.

98 One base for this imagery was the story of Odysseus, who, having himself tied to the mast of his ship could resist the sirens' song, and was therefore considered a pagan type of Christ. See Rahner, Hugo: Greek Myths and Christian Mystery, New York: Biblo and Tannen, 1971. 328-386.

${ }_{99}$ Lentes, Thomas: Die Barke zur Ewigkeit, der Mastbaum und die Waage des Kreuzes, in Glaube Hoffnung Liebe Tod - Von der Entwicklung religiöser Bildkonzepte (exhibition catalogue), eds. GEISSMAR-Brand, Cristoph - Louis, Eleonora, Wien: Kunsthalle, 1995. 194.

100 Examples: Winand von Steeg, Adamas colluctancium aquilarum, 1419, fol. 66r, The ship of the church. Biblioteca Apostolica Vaticana, Pal. lat. 412, see MArosi, Ernó: Winand von Steeg: Adamas colluctancium aquilarum, in Sigismundus rex et imperator. Múvészet és kultúra Luxemburgi Zsigmond korában. 1387-1437 [Art and Culture in the Age of Sigismund of Luxemburg. 1387-1437], ed. TAKÁCS, Imre, Mainz am Rhein: Verlag Philipp von Zabern, 2006. cat. no. 5.35, 464; Hans von Kulmbach: Das sinkende Schiff der Kirche, woodcut from the Speculum naturalis coelestis \& propheticae visionis by Joseph Grünpeck, Nürnberg, 1508, see LEIBFRIED, Stephan WinTER, Wolfgang: Ships of Church and State in the SixteenthCentury Reformation and Counterreformation: Setting Sail for the Modern State, Badia Fiesolana: European University Institute, 2014. 14.

${ }^{101}$ Bartholomäus Kistler: Von Sant Ursulen schifflin. Strassburg, 1497, see DeKIERT, Marcus: Bartholomäus Kistler, in Spätmittelalter am Oberrhein. Große Landesausstellung BadenWürttemberg 29. September 2001 - 3. Februar 2002. Teil 1. Maler und Werkstätten 1450 - 1525, ed. LÜDKE, Dietmar, Stuttgart: Thorbecke, 2001. 390-391, Fig. 228.

102 ZEHNDER, op. cit. 1987, Taf. 1.

${ }^{103}$ Jn Cruce hac Christi pugnemus fortiter om(n)es: Nec nos Conturbe(n)t crudeli morte tÿra(n)ni: Nam hoc triste malum sequitur mox vita p(er)hemnis 1496, see BARTUSCH, Ilas: Baden-Baden-Lichtental, Kloster Lichtenthal, Klosterkirche/ Fürstenkapelle, in Die Deutschen Inschriften 78, Stadt BadenBaden und Landkreis Rastatt, no. 127 (http://www.inschriften.net/baden-baden-und-landkreis-rastatt/inschrift/nr/ di078-0127.html\#content, last accessed June 2017).

${ }^{104}$ Morrall, Andrew: Jörg Breu the Elder: Art, Culture and Belief in Reformation Augsburg, Aldershot: Ashgate, 2001. 189-192, Fig. 3.24.

${ }^{105}$ A notable difference from most other compositions is that in Székelydálya the cross of Christ does not effectively form the mast of the ship, but rather hovers before it in the air as a vision, and that it is supplemented with the mourning figures of the Virgin Mary and Saint John.

${ }_{106}$ About this composition see: JÁNó, Mihály: A székelydályai református templom kutatása [The Investigation of the Protestant Church in Székelydálya], Müemlékvédelmi Szemle 1993. 35; GERMAN, op. cit., 256-257; JENEI, op. cit., 22 and SzABÓ, op. cit., 6.

107 Similar identification: JENEI, op. cit., 22 and SZABÓ, op. cit., 6 .

108 DufFy, Eamon: Saints and Sinners: A History of the Popes, New Haven - London: Yale University Press, 2006. 182.

109 See also SzABÓ, op. cit., 6.

110 WebB, Diana: Medieval European Pilgrimage, c. $700-c$. 1500, Basingstoke: Palgrave, 2002. 162-163.

111 BENKÓ, Elek: Erdély középkori harangjai és bronz keresztelómedencéi [Medieval Bells and Bronze Baptismal Fonts of Transylvania], Budapest-Kolozsvár: Teleki László Alapítvány - Polis, 2002. 188-189. 
112 SzABÓ, op. cit., 6; KovÁCS András: Középkori erdélyi zarándokok [Medieval Pilgrims from Transylvania], Dolgozatok az Erdélyi Múzeum Érem-és Régiségtárából 6-7. 20112012. 213

113 Timmermann, op. cit., 270.

${ }^{114}$ The wall paintings are earlier than the sacrament house dated to around 1490-1500. Although their exact dating is uncertain, they may be contemporary with the rest of the Late Gothic wall painting decoration of the church interior, finished in 1483-1484 following the completion of the church's reconstruction. See GERMAN, op. cit., 250, 281 and JenEI, Dana: Pictura murală a bisericii „din Deal” din Sighisoara [The Wall Painting of the Church "on the Hill" in Sighisoara], Ars Transsilvaniae 14-15. 2004-2005. 107-109. 115 See also Ibid., 109.

${ }^{116}$ As the arrowhead does not survive, the identification is hypothetical; still, the relatively short stick serving as the attribute of the saintly princess is most plausibly an arrow.

${ }^{117}$ For an analysis of this shift in Saint Barbara's iconography, see CASSIDY-Welch, Megan: Prison and Sacrament in the Cult of Saints: Images of St Barbara in Late Medieval Art, Journal of Medieval History 35/4. 2009. 371-384.

118 Bynum, Caroline Walker: Holy Feast and Holy Fast: the Religious Significance of Food to Medieval Women, Berkeley: University of California Press, 1987. 81; DAMBECK, op. cit., 27-28. Saint Barbara also appears frequently with her eucharistic attributes in Transylvanian winged altarpieces. On her cult among the Transylvanian Saxons and her representations see CRĂCIUN, Maria: The Cult of St Barbara and the Saxon Community of Late Medieval Transylvania, in Identity and Alterity in Hagiography and the Cult of Saints, eds. MARINCOVIĆ, Ana - Vedriš, Trpimir, Zagreb: Hagiotheca, 2010. 137-163.

119 TimmermanN, op. cit., 306.

${ }^{120}$ Rubin, Miri: The Eucharist and the Construction of Medieval Identities, in Culture and History 1350-1600: Essays on English Communities, Identities and Writing, ed. AERs, David, New York: Harvester Wheatsheaf, 1992. 59.

${ }^{121}$ CRĂCIUN, op. cit., 139
122 Timmermann, Achim: Staging the Eucharist: Late Gothic Sacrament Houses in Swabia and the Upper Rhine, Ph.D. dissertation, Courtauld Institute, University of London, 1996. 252.

123 PopA, Corina: Pictura murală a 'Bisericii din Deal' Sf. Nicolae și istoria orașului Sighișoara [The Wall Painting of the Saint Nicholas Church and the History of the Town of Sighișoara], Ars Transsilvaniae 8-9. 1998-1999. 181.

${ }^{124}$ Dana Jenei has read a part of the inscription as S. MARIA MAGDALENA. 1484, see JENEI, op. cit., 2005, 112.

125 POPA, op. cit., 180.

126 The Noli me tangere being represented on the northern wall of the tower base. On this composition see SARKAD NAGY, Emese: Összefüggések néhány segesvári falkép kapcsán [Considerations Regarding the Wall Paintings from Sighișoara, the Church on the Hill], in Középkori egyházi épitészet Erdélyben V [Medieval Ecclesiastical Architecture of Transylvania V], ed. SzŐ́cs, Péter Levente, Satu Mare: Editura Muzeului Sătmărean, 2012. 343.

127 Jansen, Katherine Ludwig: The Making of the Magdalen. Preaching and Popular Devotion in the Later Middle Ages, Princeton, New Jersey: Princeton University Press, 2000. 203-206.

${ }^{128}$ Around 1490-1500, see FIREA, op. cit., II. 344-345.

129 JANSEN, op. cit., 199-201.

130 See Rubin 1991, op. cit., 84.

131 JANSEN, op. cit., 222-224.

132 The Golden Legend, 381.

133 BYNUM, op. cit., 81.

134 JANSEN, op. cit., 222.

135 Timmermann, op. cit., 49-51, Fig. 50.

136 LiNDGREN, Mereth: Sakramentsskåpens ikonografi, in Ting och Tanke. Ikonografi pa liturgiska föremal, ed. PEGELOW, Ingalill, Stockholm: Kungl. Vitterhets Historie och Antikvitets Akademien, 1998. 172.

${ }^{137}$ As an exception, a depiction of Saint Francis receiving the wounds of Christ on the north wall of the tower base in the Saint Nicholas church in Segesvár seems to be thematically linked to the neighbouring Passion scenes and may have a eucharistic connotation, see DitTMEYER, op. cit., 143. 